Geology and Ground-Water Resources of Oswego County. New York

U.S. GEOLOGICAL SURVEY

Water Resources Investigations $81-60$

Prepared in cooperation with

OSWEGO COUNTY PLANNING BOARD

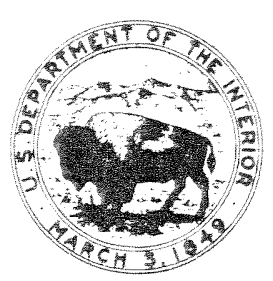

usG

purs

$(200)$

(WO

$81-60$ 


\begin{tabular}{|c|c|c|}
\hline $\begin{array}{l}\text { REPORT DOCUMENTATION } \\
\text { PAGE }\end{array}$ & 1. REPORT NO. & 3. Recipient's Accession No. \\
\hline \multirow{2}{*}{\multicolumn{2}{|c|}{$\begin{array}{l}\text { 4. Title and Subtitle } \\
\text { Geology and ground-water resources of Oswego County, } \\
\text { New York }\end{array}$}} & \multirow{2}{*}{$\begin{array}{l}\text { 5. Report Date } \\
1982 \\
6 .\end{array}$} \\
\hline & & \\
\hline \multicolumn{2}{|l|}{$\begin{array}{l}\text { 7. Author(s) } \\
\text { Todd S. Milier }\end{array}$} & $\begin{array}{l}\text { 8. Performing Organization Rept. No. } \\
\text { USGS/WRI } 81-60\end{array}$ \\
\hline \multirow{2}{*}{\multicolumn{2}{|c|}{$\begin{array}{l}\text { 9. Performing Organization Name and Address } \\
\text { U.S. Geological Survey } \\
\text { Water Resources Division } \\
343 \text { U.S. Post Office \& Courthouse } \\
\text { Albany, New York } 12201\end{array}$}} & 10. Project/Task/Work Unit No. \\
\hline & & $\begin{array}{l}\text { 11. Contract(C) or Grant(G) No. } \\
\text { (C) } \\
\text { (G) }\end{array}$ \\
\hline \multirow{2}{*}{\multicolumn{2}{|c|}{$\begin{array}{l}\text { 12. Sponsoring Organization Name and Address } \\
\text { U.S. Geological Survey } \\
\text { Water Resources Division } \\
343 \text { U.S. Post Office \& Courthouse } \\
\text { Albany, New York } 12201\end{array}$}} & $\begin{array}{l}\text { 13. Type of Report \& Period Covered } \\
\text { Final }(1979-80)\end{array}$ \\
\hline & & 14. \\
\hline
\end{tabular}

15. Supplementary Notes

16. Abstract (Limit: 200 words)

Unconsolidated deposits of Pleistocene and Holocene age form a nearly continuous cover in Oswego County. Pleistocene deposits consist of lodgment and ablation tills; outwash; kame, beach, and wave-delta sand and gravel; and lacustrine sand, silt, and clay. Holocene deposits consist of peat and muck deposited in wetlands and alluvial silt, sand, and gravel deposited in stream valleys.

Unconsolidated deposits contain sufficient water for domestic and small farm needs except in areas mantled by silt and clay. Sand and gravel deposits are the best source of large quantities of water. Aquifers in glacial outwash are common in the eastern Tug Hill region, whereas kame, esker-kame, and beach aquifers predominate in the eastern and central regions. The principal sand and gravel aquifer, known as the Lacona-Williamstown aquifer, is 20 miles long, 0.5 to 3 miles wide, and 10 to 85 feet thick. Wells tapping the aquifer yield from 220 to 800 gallons per minute.

Fracturing, rather than rock type, is the controlling factor in the waterproducing capacity of bedrock. Bedrock near or at the land surface provides adequate supplies for domestic and farm needs. Shallow wells in bedrock generally have water of fair to good quality, but mineral content increases with depth.

17. Document Analysis a. Descriptors

Glacial drift, Ground-water resources, Water wells, Glacial aquifers

b. Identifiers/Open.Ended Terms

Glacial geology; Oswego County, N.Y.

c. COSATI Field/Group

18. Availability Statement

No restriction on distribution

\begin{tabular}{|c|c|}
\hline $\begin{array}{l}\text { 19. Security Class (This Report) } \\
\text { UNCLASSIEIED }\end{array}$ & $\begin{array}{l}\text { 21. No. of Pages } \\
41\end{array}$ \\
\hline $\begin{array}{l}\text { 20. Security Class (This Page) } \\
\text { UNCLASS IFIED }\end{array}$ & 22. Price \\
\hline
\end{tabular}

OPTIONAL FORM 272 (4-77) (Formerly NTIS-35) Department of Commerce 
GEOLOGY AND GROUND-WATER RESOURCES OF

OSWEGO COUNTY, NEW YORK

By Todd S. Miller

Water-Resources Investigations 81-60

Prepared in cooperation with

OSWEGO COUNTY PLANNING BOARD

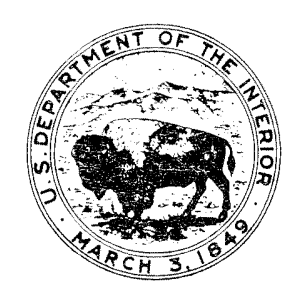

Tthaca, New York 
UNITED STATES DEPARTMENT OF THE INTERIOR

JAMES G. WATT, Secretary

GEOLOGICAL SURVEY

Dallas L. Peck, Director

For additional information write to:

U.S. Geological Survey

521 W. Seneca Street

Ithaca, New York 14850

(607) 272-8722 
Page

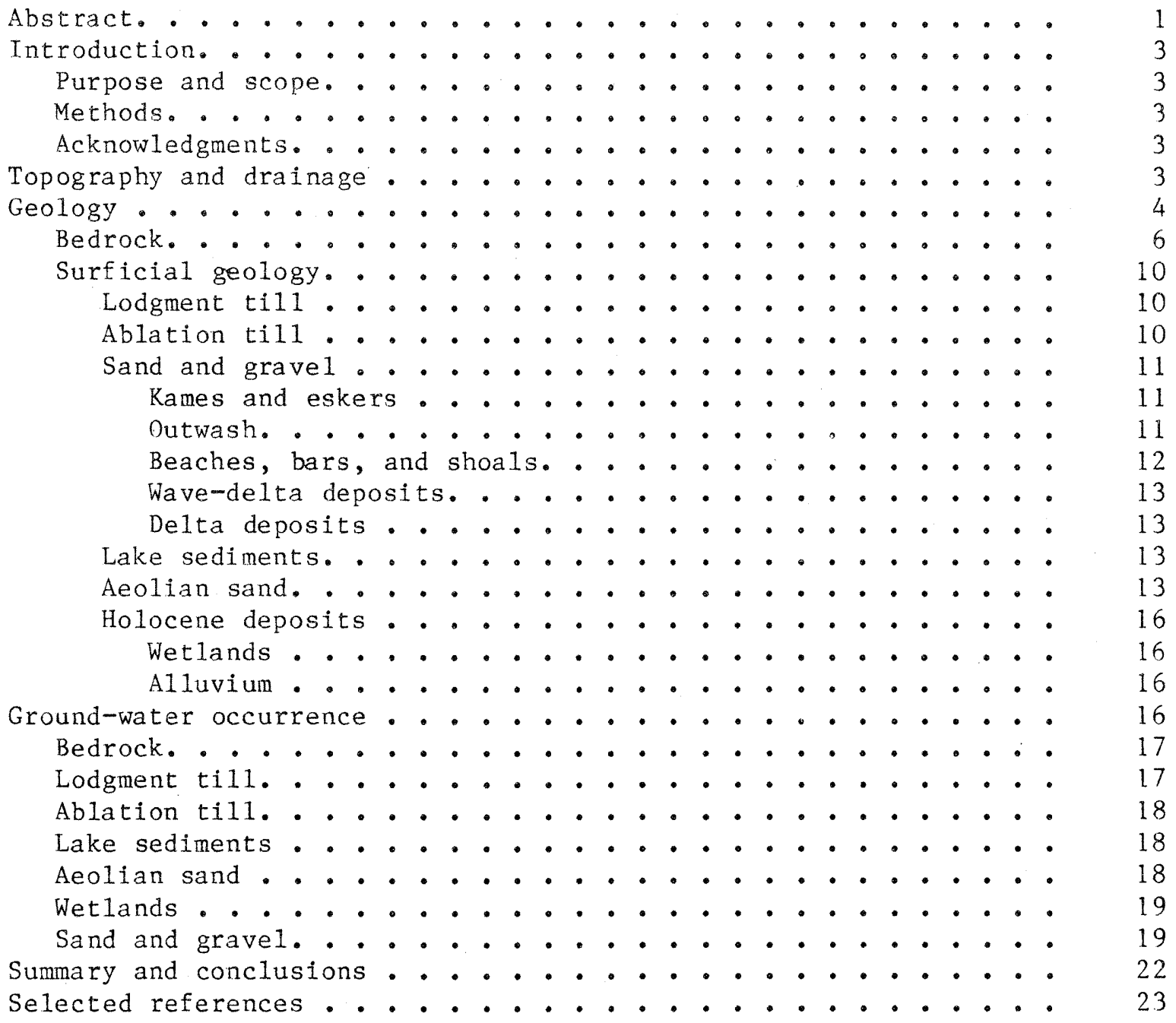

\section{ILLUSTRATIONS}

Figure 1.--Map showing location of Oswego County and physiographic provinces of New York. . . . . . . . . . .

2.--Map showing surficial geology of Oswego County . . •

3.--Diagram showing mode of deposition of common glacial deposits . . . . . . . . . . . . . . . .

4.--Cross section showing relative position of bedrock formations in Oswego County. . . . . . . . . . . 
5.--Map showing bedrock geology of Oswego County $\ldots . . . \quad 8$

6.--Location of quadrangles and geographic features

referred to in text. . . . . . . . . . . . . . 9 9

7.--Generalized section in Fulton quadrangle showing location of typical beach and wave-delta deposits. . . . 14

8.--Cross section of typical drumlin and interdrumlin deposits . . . . . . . . . . . . . . 15

9.--Map showing location of potential sand and gravel aquifers in Oswego County. . . . . . . . . . 20

10.--Map showing location of Oswego County wells and test holes listed in table 1. . . . . . . . . . . . .

\section{TABLE}

Table 1.--Records of selected wells in Oswego County . . . . .

\section{CONVERSION FACTORS AND ABBREVIATIONS}

Factors for converting the units used in this report to International system (SI) of metric units are shown below.

\section{Multiply}

inch (in)

foot ( $\mathrm{ft}$ )

mile (mi)

square mile (mi )

gallons per minute (gal/min)

million gallons per day (Mgal/d)

feet per mile ( $\mathrm{ft} / \mathrm{mi}$ )

gallons per day (gal/d)

feet per day ( $f t / d$ )

feet squared per day (ft/d)
By

2.54

.3048

1.609

2.590

.06309

.04381

.1894

3.785

.3048

.0929
To obtain SI units

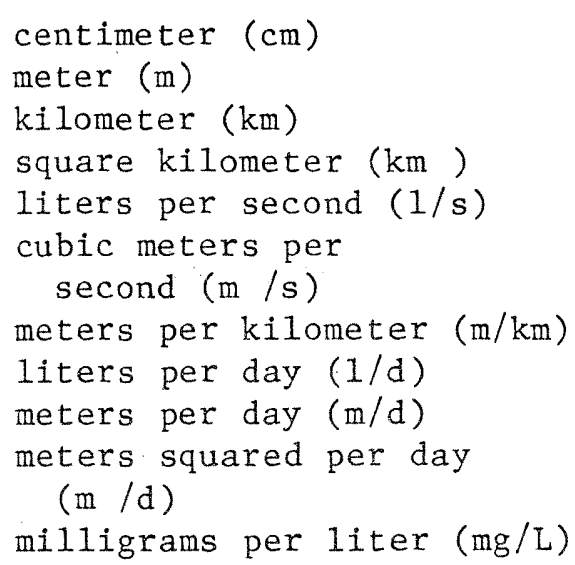




\title{
GEOLOGY AND GROUND-WATER RESOURCES OF OSWEGO COUNTY, NEW YORK
}

\author{
by
}

Todd S. Miller

\begin{abstract}
Unconsolidated deposits of Pleistocene and Holocene age form a nearly continuous cover in Oswego County. Pleistocene deposits consist of lodgment and ablation tills, outwash, kame, beach and wave-delta sand and gravel, and lacustrine sand, silt, and clay. Holocene deposits consist of peat and muck deposited in wetlands, and alluvial silt, sand, and gravel deposited in stream valleys.

Unconsolidated deposits contain sufficient water for domestic and small farm needs except in areas mantled by silt and clay. Sand and gravel deposits are the best source of large quantities of water. Aquifers in glacial outwash are common in the eastern Tug Hill region, whereas kame, esker-kame, and beach aquifers predominate in the eastern and central regions. The principal sand and gravel aquifer, known as the Lacona-Williamstown aquifer, is 20 miles long, 0.5 to 3 miles wide, and 10 to 85 feet thick. Wells tapping the aquifer yield from 220 to 800 gallons per minute.

Fracturing, rather than rock type, is the controlling factor in the water-producing capacity of bedrock. Bedrock near or at land surface provides adequate supplies for domestic and farm needs. Shallow wells in bedrock have water of fair to good quality, but mineral content increases with depth.
\end{abstract}




\section{INTRODUCTION}

Oswego County, in north-central New York, has an area of $964 \mathrm{mi}^{2}$. Approximately 70 percent of the county's residents depend on ground water. A thorough knowledge of the local hydrogeology is needed to aid the county in developing and managing its ground-water resources.

\section{Purpose and Scope}

This report describes the relationship between geology and ground-water occurrence in Oswego County and indicates how much ground water is likely to be available in any given area. It is a companion to a series of 29 maps produced during 1978-801 to document the surficial deposits in the county's 29 quadrangles and includes a compilation of data on representative wells in each quadrangle.

\section{Methods}

Surficial geology and well locations were compiled on the 7.5-minute topographic quadrangle maps cited in the list of references. Well data were collected from well owners, drillers, and public and industrial supply records to document ground-water conditions. Data from selected wells are presented in table 1 (at end of report).

\section{Acknowledgments}

This study was done in cooperation with the Oswego County Planning Board. Thanks are given to the Oswego County Planning Board, drillers, and individual well owners who provided well information, and to Dr. Ernest H. Muller of Syracuse University for his assistance in mapping and for providing information on geologic conditions.

\section{TOPOGRAPHY AND DRAINAGE}

Oswego County lies within parts of two physiographic provinces--the Erie-Ontario Plain and the Tug Hill Plateau (fig. 1; also Miller, 1924). The western and central parts (Erie-Ontario Plain) consist of gently rolling hills ranging in altitude ${ }^{2}$ from 246 to $600 \mathrm{ft}$; the northeastern section, which occupies part of the Tug Hill Plateau, slopes northeastward from the former shoreIine of proglacial Lake Iroquois at $500 \mathrm{ft}$ to the northeast corner of Oswego County at $1,720 \mathrm{ft}$ (fig. 2). Location of Oswego County in relation to the physiographic provinces of New York State is shown in figure 1.

Glacial deposits overlie most of Oswego County. The Erie-Ontario Plain is characterized by numerous long, parallel, elliptical hills called drumlins; the Tug Hill Plateau contains irregular, low, knobby mounds of ablation moraine overlying drumlins and bedrock.

1 Quadrangle maps are listed in references section.

2 Altitudes are in feet above National Geodetic Vertical Datum of 1929 (NGVD).

$$
(2-B \operatorname{lank}) \quad 3
$$


The entire county lies within the Lake Ontario drainage basin. Stream gradients on the Erie-Ontario Plain are low, but in the Tug Hill region, they range from low to steep. Major factors that control the direction of streamflow are the regional bedrock slope toward Lake Ontario and orientation of the drumlins.

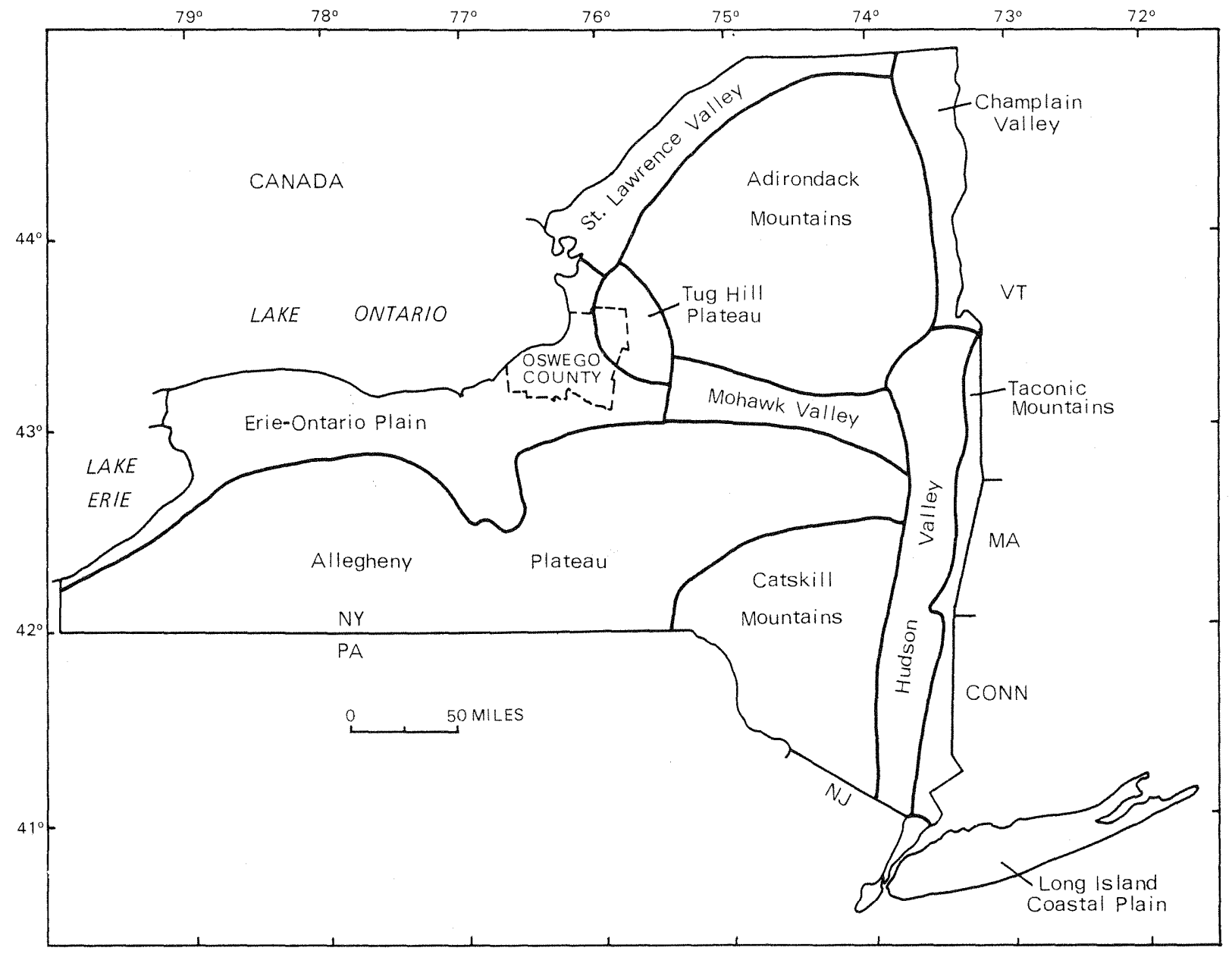

Figure 1.--Location of Oswego County and physiographic provinces of New York (Modified from Mizler, 1924.)

\section{GEOLOGY}

Unconsolidated Quaternary sediments, deposited during and after the last glaciation (Wisconsinan), overlie most of the bedrock surface (fig. 2). Some bedrock is exposed where erosion has removed the overlying glacial sediments along segments of the Lake Ontario shoreline, in glacial meltwater channels on the Tug Hill Plateau, and in some channels of present drainage systems. These exposures indicate that the bedrock surface has a low and gently undulating relief in the Erie-Ontario Plain and a gently sloping surface with many deep ravines incised by glacial meltwater on the Tug Hill Plateau. 
$76^{\circ} 30^{1}$ $76^{\circ} 15^{\prime}$

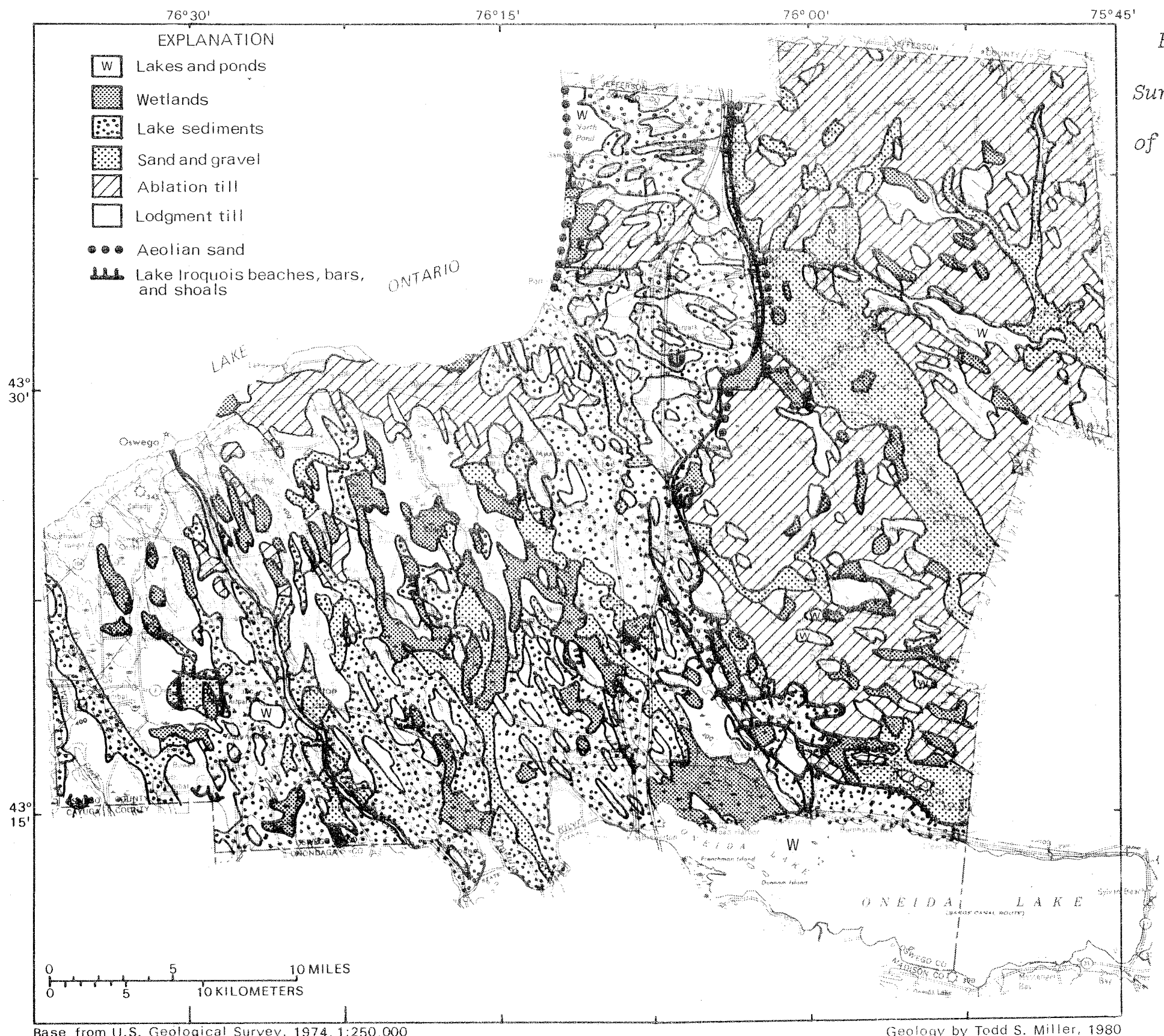

Figure 2.

Surficial geology

of Oswego County. 
lacial deposits consist of lodgment and ablation tills; kame, esker, outwash, beach and wave-delta sand and gravels; and proglacial lake deposits of fine sand, silt, and clay. End or recessional moraines deposited at the ice front form arcuate ridges consisting of ablation and lodgment tills. Ground moraine consisting predominantly of lodgment till but commonly having a veneer of ablation till at the surface forms drumlins. The origin of selected types of glacial deposits is depicted in the geologic section in figure 3 ; the distribution of these deposits is shown in figure 2. The surficial geology is shown in greater detail in the 29 quadrangle maps prepared during this study. (See list of references.)

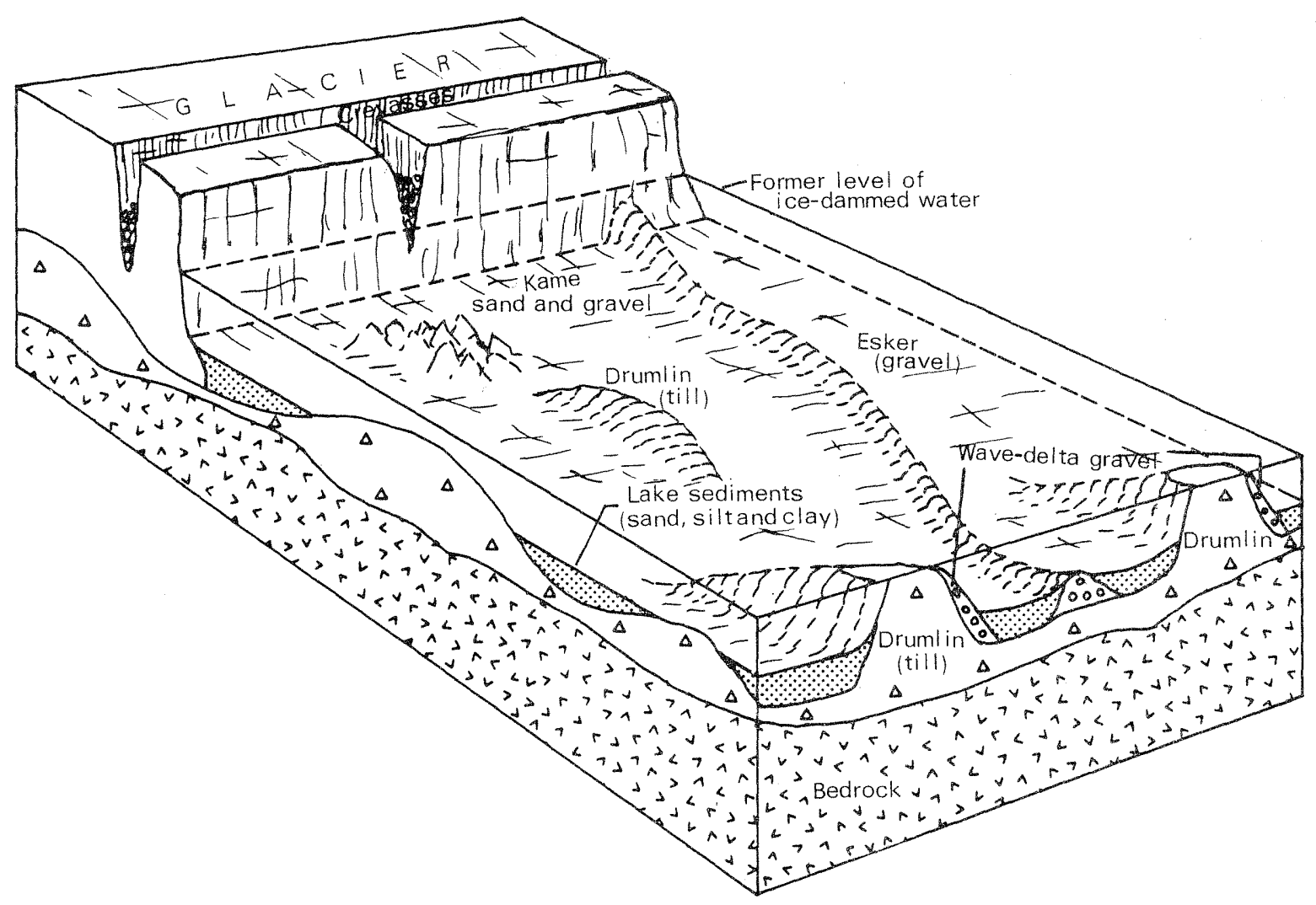

Figure 3.--Mode of deposition of common glacial deposits.

\section{Bedrock}

The bedrock consists of nearly flat-lying Ordovician and Silurian sedimentary formations that were deposited in marine and terrestrial environments 400 to $500 \mathrm{milli}$ on years ago (Broughton and others, 1970). Older formations of Late Ordovician age crop out in northern Oswego County, and successively younger formations are exposed from there southward (figs. 4, 5). The younger rock units overlie the older units so that the age of units increases with depth. Bedrock dips to the southwest at approximately $50 \mathrm{ft} / \mathrm{mi}$. A section of the bedrock formations is shown in figure 4 . 

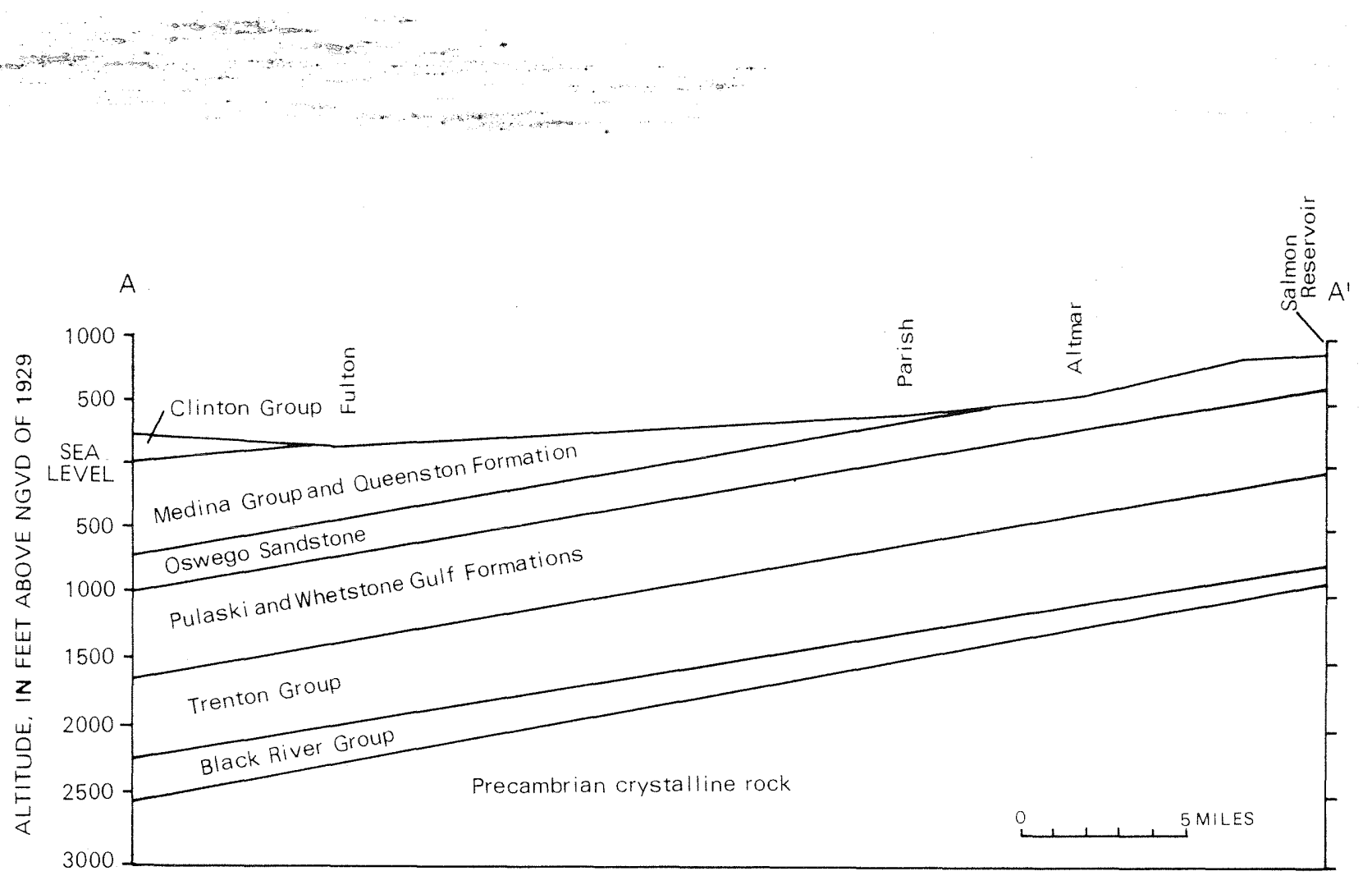

Figure 4.--Section showing relative position of bedrock formations in oswego County. Location of section is shown in figure 5 .

The oldest exposed formations are the fossiliferous Pulaski Formation and the Whetstone Gulf Formation (the local name), which grade upward from predominantly shale in the Whetstone Gulf and lower part of the Pulaski to siltstone in the upper part of the Pulaski (figs. 4 and 5). The overlying Oswego Sandstone grades upward from shale to very fine-grained sandstone in the lower part to fine-grained sandstone in the upper part.

The Queenston Formation and Medina Group (designated Albion Group by the U.S. Geological Survey) are commonly mapped together because they are difficult to differentiate. Both contain red shale, siltstone, and sandstone, and both were deposited under tidal flat and deltaic conditions (Patchen, 1978 p. 368). Exposure of Queenston and Medina sediments to an aerobic environment allowed iron to oxidize and produced the red color. Together the Pulaski, Oswego, and Queenston sequence represents the Queenston Delta, which extended westward from the ancient Taconic Mountains in the eastern part of New York State (fig. 1), the source of sediment for these formations.

Overlying and cropping out south of the Queenston-Medina sequence is the Clinton Group (figs. 4 and 5 ), which consists of green and gray marine sandstone, siltstone, shale, and hematitic limestone. The Clinton rocks are the youngest in the county.

Two significant bedrock troughs have been noted--the Salmon River trough near the village of Redfield and the Ninemile Creek trough west of the village of Hannibal (fig. 6). These troughs are preglacial valleys that were alined in the direction of glacier flow and extensively scoured. These troughs are typically U-shaped and contain varying amounts of drift. 


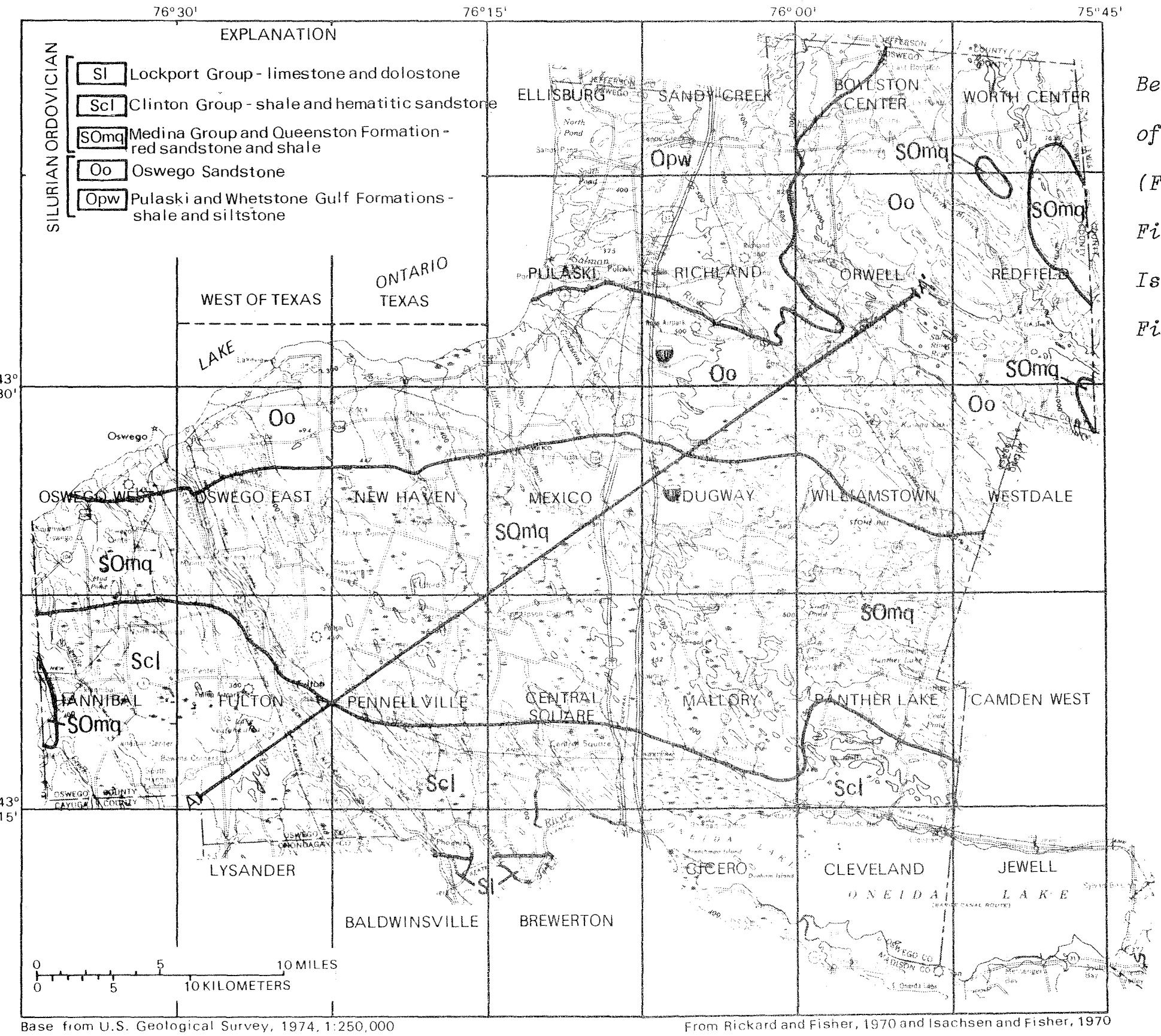

Figure 5.

Bedrock geology

of Oswego County.

From Rickard and

Fisher, 1970, and

Isachsen and

Fisher, 1970. 


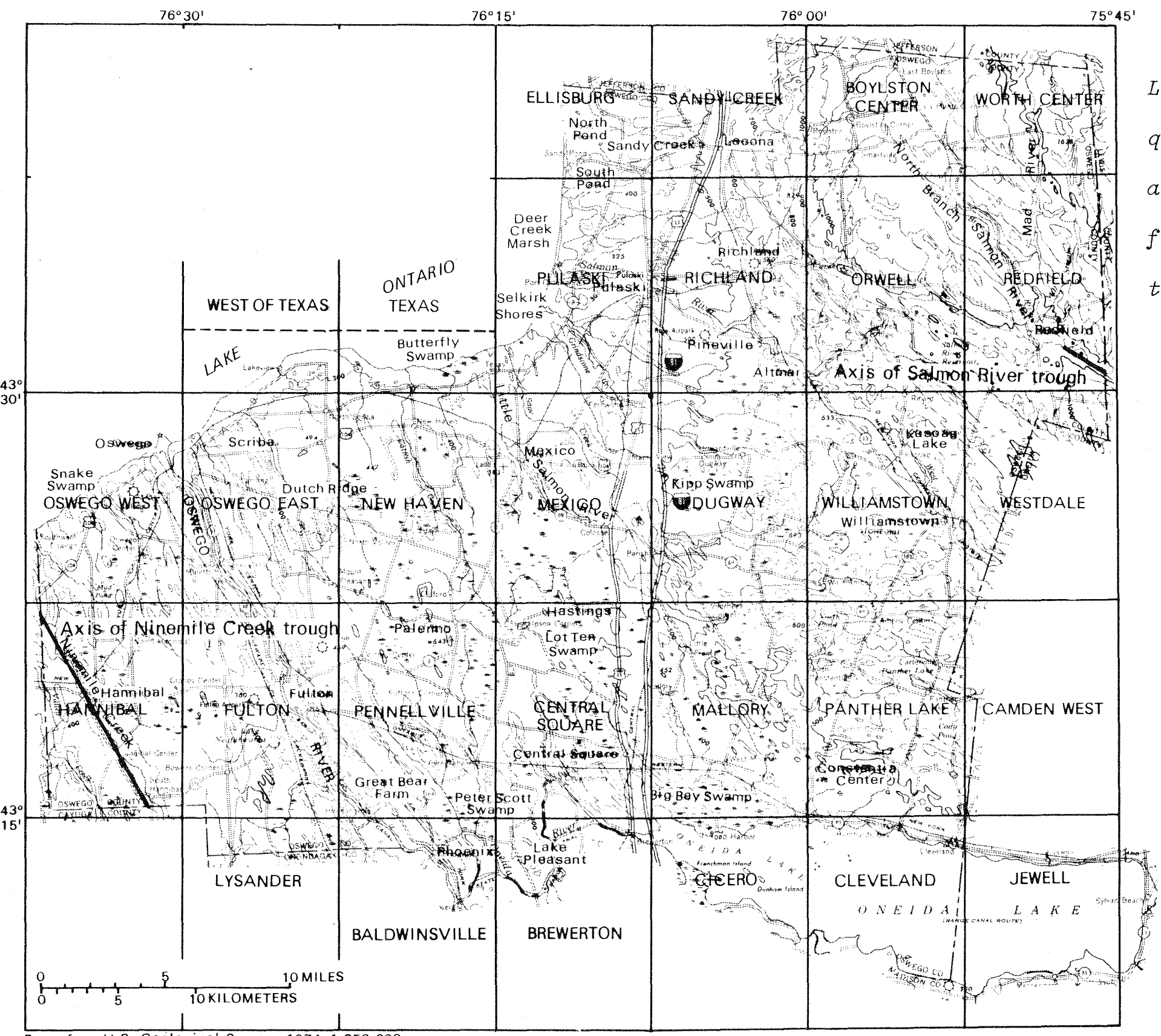

Figure 6. Location of quadrangles and geographic features referred to in text. 


\section{Surficial Geology}

The unconsolidated materials that cover the bedrock were deposited during and after the advance of Pleistocene ice sheets. The common types of deposits and their mode of formation are described in the paragraphs that follow.

\section{Lodgment Tizl}

Lodgment till was deposited beneath the advancing glacier and consists of poorly sorted sediments ranging in size from clay to boulders. This compact material was compressed beneath the advancing ice and is typically dense, firm, and relatively impermeable. Lodgment till contains pebbles and cobbles alined in the direction of glacier flow and, when exposed to air, developes a platy structure.

Typically at least 80 percent of the material that forms lodgment till is derived from local bedrock. For example, in the northern part of the county, till overlying the green Oswego Sandstone is olive green, and in the southern part of the county, till overlying red sandstones has a characteristic red color. Particle-size analyses by Soloman (1974) of till matrix from the Lake Ontario shore west of the city of Oswego revealed nearly equal proportions of sand and silt ( 45 percent each) and about 10 percent clay.

Lodgment till forms most of the 20- to 150-ft high drumlins that dominate the topography. The main axis of drumlins is alined with the direction of glacier flow (south to southeastward). Their lower parts are commonly covered with lake sediments or wetlands.

\section{Ablation Till}

Ablation till is drift that was carried on top of or within a glacier and was deposited as the ice melted. Ablation till in Oswego County consists of poorly sorted material ranging in size from silt to boulders and tends to be coarser, looser, and more permeable than lodgment till. Stones tend to be broken by frost action and are more angular than those in lodgment till. Till fabric or structure is absent except in local patches of stratified drift showing evidence of washing.

An extensive blanket of ablation moraine overlying lodgment till or bedrock covers a large part of the Tug Hill Plateau and the region just south of it (fig. 2). Till in this region has a silty sand matrix with pebbles and cobbles. Land surface of the Tug Hill area is characterized by a blanket of irregular knobs that are in places alined in arcuate ridges that mark temporary standstills of the ice front.

Ablation till forms the end moraine in the Texas and West of Texas quadrangles and the northern parts of the Oswego East, New Haven, and Mexico quadrangles (fig. 6). Till in this moraine contains large blocks of Oswego Sandstone and forms well-defined, arcuate, knobby ridges that reflect former ice-margin positions. This belt of ablation till is the result of a minor glacial readvance. Elsewhere, ablation till is present only in small patches of irregular relief. 
Sand is detrital material ranging from 0.005 to 0.08 inches in diameter; gravel is made up of particles ranging from 0.08 to 3.0 inches in diameter. Sand and gravel have a high porosity and are unconsolidated except where secondary calcite in ground water has cemented the grains.

In the western and central parts of the county, sand and gravel occurs in irregular patches of conical mounds or as long, sinuous deposits; in the east it occurs as linear deposits and as wide belts (fig. 2). In the detailed quadrangle maps cited in the list of references, sand and gravel deposits are differentiated according to mode of deposition; these forms include kame and esker, outwash, beach, wave-delta, delta, and aeolian deposits. Each of these is described in paragraphs that follow.

Kames and eskers.--Crevasses and openings in a glacier that became filled with sediment left conical mounds of stratified sand and gravel when the ice melted. Such deposits, known as kames, may consist of sand, gravel, or both. When sediments were deposited in streams flowing in subglacial tunnels, they formed long, sinuous ridges called eskers.

Significant kame deposits occur near Fulton in Fulton quadrangle, at Great Bear Farm in Pennelville quadrangle, near Lake Pleasant in Brewerton quadrangle, in areas south and east of Mexico in Mexico quadrangle, at Hastings in Central Square quadrangle, at the eastern margin of Central Square quadrangle, near Constantia Center in Panther Lake quadrangle, and southeast of Redfield in Redfield quadrangle (fig. 6). The largest esker-kame deposit forms a part of a sand and gravel complex also consisting of outwash, beach, and aeolian sediments that extends from Lacona to Williamstown (fig. 2). The Lacona-Williamstown deposit is $20 \mathrm{mi}$ long, 0.5 to $3 \mathrm{mi}$ wide, and 10 to $85 \mathrm{ft}$ thick. This deposit was formed by ice-contact sediments accumulating at a stagnant ice front and by outwash and beach deposition. Sand and gravel deposits accumulated until the glacier's melting rate exceeded its rate of advance and the ice front retreated to the northwest. Smaller kame deposits are common throughout oswego County.

Most of the kame deposits are associated with eskers. Glacial streams channeled sediment-laden meltwater on top of and within the ice southeastward to the ice margin. In the central part of the county, where subglacial tunnels connected with subglacial caverns, many eskers are associated with large kame deposits.

Also associated with kame deposits are bowl-shaped depressions called kettles, generally 10 to $25 \mathrm{ft}$ deep, which were formed by the melting of buried or isolated ice blocks. When these depressions filled with water, they formed kettle lakes, of which Kasoag Lake in Williamstown quadrangle (fig. 6) is an example.

Outwash.--Stratified sand and gravel deposited by glacial meltwater beyond the ice front is known as outwash. Outwash that was deposited close to the ice front consists of coarse sand and gravel that could not be moved readily; the material at greater distances grades into progressively finer grained deposits. Outwash deposits typically form plains and valley trains having relatively flat surfaces that slope gently away from the former ice front. 
Because outwash is formed by fluvial processes, it is uncommon in the western and central parts of Oswego County, which were lnundated by proglacial Lake Iroquois (fig. 2) below 480 to $500 \mathrm{ft}$. One end moraine with an associated outwash plain, $1.5 \mathrm{mi}$ east of Scriba in the Oswego East quadrangle (fig. 6), was just above lake level.

On the west margin of the Tug Hill Plateau, which was above Lake Iroquois, ice-marginal streams along the east edge of the retreating Ontario ice lobe deposited much outwash. Meltwater streams flowing south and southwestward along the ice margin carved deep incisions into bedrock and lodgment till and deposited sediments where stream gradients decreased. Outwash deposits left by ice-marginal meltwaters are visible along the west margin of the Tug Hill Plateau in the Sandy Creek, Boylston Center, Redfield, Richland, and Orwell quadrangles (fig. 2). (See also maps cited in list of references.)

The largest outwash deposit is in the preglacial valley of North Branch Salmon River in the Tug Hill Plateau (fig. 6). This valley was parallel to the direction of ice flow and thus received meltwaters carrying outwash for a longer time than the numerous short-lived, ice-marginal meltwaters.

Beaches, bars, and shoals.--Prominent beaches, bars, and shoals developed approximately 12,000 years ago along the shore of proglacial Lake Iroquois, which inundated most of western and central Oswego County. This lake formed in a basin in front of the glacier when the meltwater outlets were dammed by ice and topographic obstructions. Locations of major beaches, bars, and shoals are shown in figure 2; the Lake Iroquois beach roughly parallels the boundary between the Erie-Ontario Plain and Tug Hill Plateau (fig. 1).

In southern Oswego County, features created or modified by wave action, such as beaches, sea cliffs, and wave-cut drumlins, indicate that Lake Iroquois reached a maximum altitude of 480 to $500 \mathrm{ft}$. The beach rises northward at approximately $4 \mathrm{ft} / \mathrm{mi}$; this rise is attributed to progressively greater crustal rebound to the north after removal of the ice load (Flint, 1971).

The Lake Iroquois beach from Lacona to Pineville (figs. 2 and 6) is exceptionally wide because large quantities of outwash sediments from the Tug Hill Plateau were being deposited in the lake, where they became reworked by wave action to form the beach.

In central and western Oswego County, less prominent shore features at altitudes of 430 to $460 \mathrm{ft}, 415$ to $425 \mathrm{ft}$, and 390 to $400 \mathrm{ft}$ (Wright, 1973) represent lower substages of Lake Iroquois. These substages are indicated mainly by flattened drumlin tops, as depicted in figure 3. Dutch Ridge, in Oswego West quadrangle (fig. 6), is a typical drumlin whose top has been eroded to a flat surface (altitude $430 \mathrm{ft}$ ). Sutton and others (1972) identified four other post-Iroquois standstills in the coastal area of the eastern ontario basin at elevations of 290 to $300 \mathrm{ft}, 255 \mathrm{ft}$, and $215 \mathrm{ft}$. During one stage, the Dune stage (altitude $215 \mathrm{ft}$ ), when Lake Ontario was $30 \mathrm{ft}$ lower than its present level, a wide beach developed that provided enough sand for dunes to form on the east side of the beach. These dunes are now partly inundated by Lake Ontario and form barrier beaches along the eastern Lake Ontario shore at North and South Ponds and Deer Creek Marsh (fig. 6). 
Recent beach deposits of Lake Ontario between Oswego County's western boundary and the mouth of Little Salmon River (fig. 6) consist of a coarse cobble gravel with intervening sea cliffs cut into drumlins or bedrock. A sandy beach formed by the reworking of dune sand has developed from the mouth of Little Salmon River to the northern border of the county.

Wave-delta deposits, -Waves on Lake Iroquois, its substages, and other postglacial lakes have exoded the tops of drumlins to altitudes corresponding with lake levels and deposited stratified sand and gravel on the lee side. The presence of gravel on only the east flanks of drumlins indicates that currents flowed from west to east. As a result of winnowing, or separation of fine particles from coarser ones by wave action, a lag of boulders remains on top of the flat-topped drumlins. Wave-delta deposits are found along drumlins in the western and central part of the county. Figure 7 shows an east-west crosssectional view through drumlin, beach, and wave-delta deposits.

Delta deposits.--The delta deposits consist of sediment deposited by meltwater flowing into Lake Iroquois from the Tug Hill Plateau. Coarse stratified sand and gravel was deposited near stream mouths, and finer material was deposited farther out in the lake. A major delta deposit is found near Pineville in Richland quadrangle (fig. 6), where Salmon River flowed into Lake Iroquois.

\section{Lake Sediments}

Lake sediments, also called lacustrine sediments, are deposits of sand, silt, and clay that settled out of suspension in lakes. The sediments of former Lake Iroquois are the most widespread type of surficial deposits in western and central oswego county (fig. 2). Sand, silt, and clay blanketed the interdrumlin lowlands, the areas offshore from the postglacial beaches, and the mouths of streams that drained the Tug Hill Plateau into Lake Iroquois. The lake sediments generally overlie lodgment till or kame deposits.

Lake currents kept the tops of inundated drumlins free of fine sediment, but fine sand accumulated on their lower flanks. This material grades into finer particles of sand, silt, and clay toward the center of interdrumlin lowlands. A typical interdrumlin deposit is depicted in figure 8. Fine sand predominates just offshore from former high-energy environments such as beaches and deltas; deposits of finer particles consisting of silt and clay formed in the quieter water farther offshore.

\section{Aeolian Sand}

Lowering of lake levels exposed sand deposits to the wind until vegetation was reestablished. Aeolian sand formed dunes on the landward side of the Lake Iroquois beach from Lacona to Altmar (figs. 2, 6) and mantled the windward side of drumlins, ablation moraine, and kame deposits downwind adjacent to the beach. Sand dunes have also collected along the east shore of Lake Ontario from Selkirk Shores to North Pond (figs. 2, 6). 


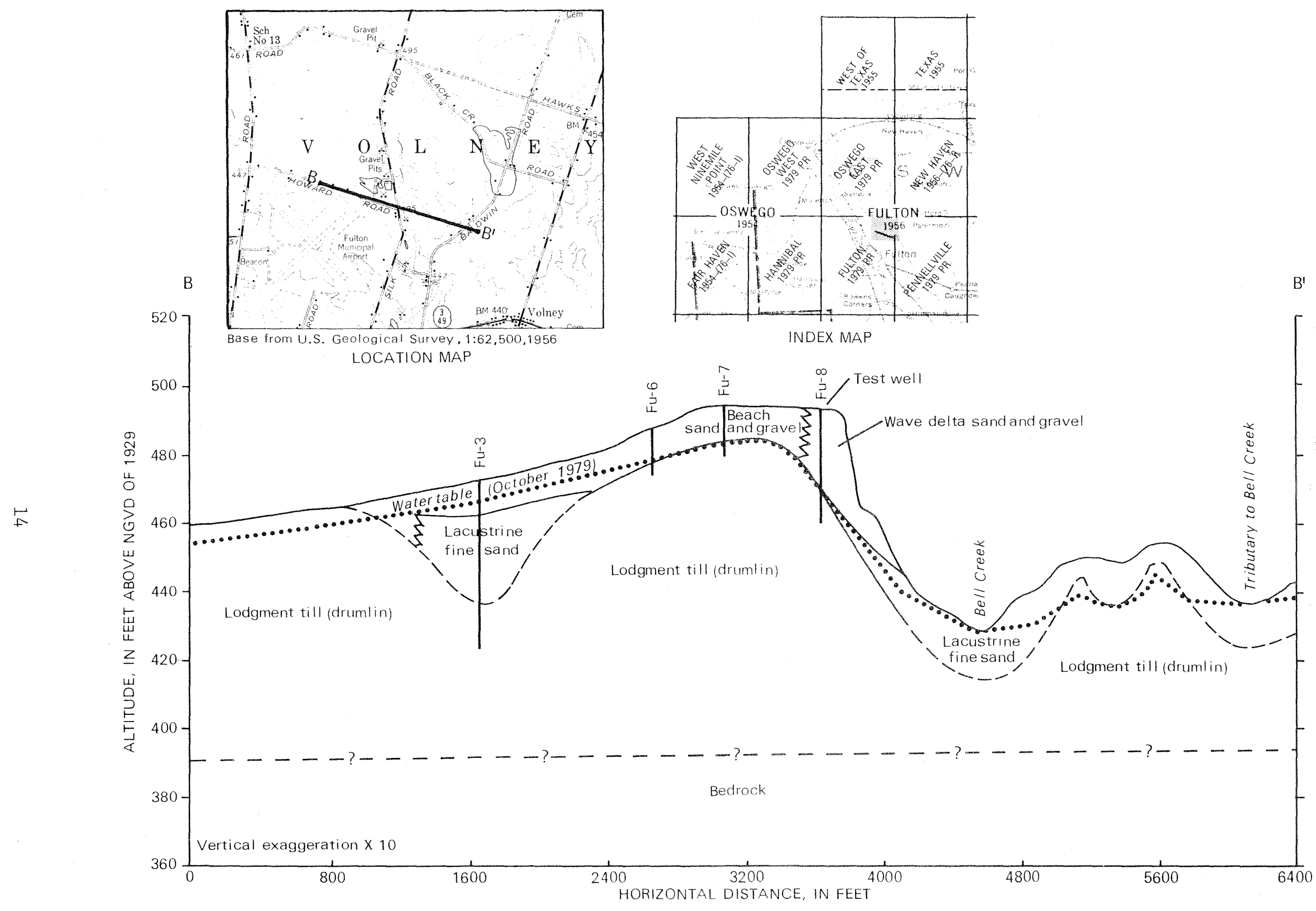

Figure 7.--Generalized section in Fulton quadrangle showing location of typical beach and wave-delta deposits. 


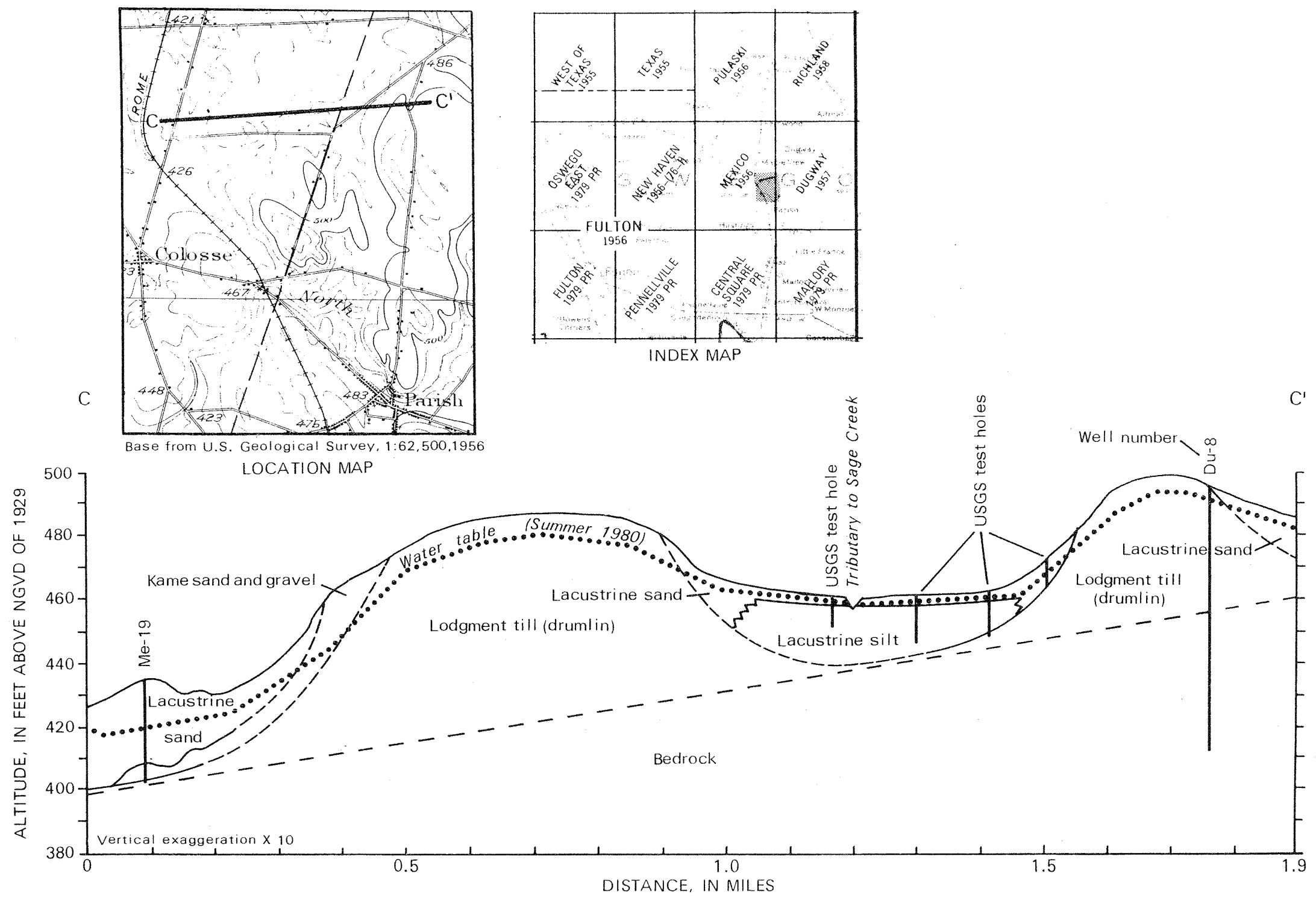

Figure 8.--Cross section of typical drumlin and interdrumlin deposits. 
Wetlands.--Oswego County contains hundreds of wetlands, most of which formed during deglaciation, when drainage in low areas became blocked by glacial debris. Wetlands consist of shallow stagnant water, organic material, marl, peat, and muck. Many of the wetlands have been drained for agricultural use. during the last two decades.

In the western and central parts of the county, wetlands comonly formed in swales, or depressions between drumlins, when the outlets were dammed by kame moraine, esker, beach, or ablation till deposits. The wetlands southeast of Palermo in Pennellville quadrangle (fig. 6) were created by esker and kame dans, and Kipp Swamp in Dugway quadrangle (fig. 6) formed behind a lake Iroquois sand bar. Other wetland remnants of Lake Iroquois are Peter Scott swamp in Baldwinsville quadrangle, Big Bay swamp in Mallory quadrangle, and Lot Ten swamp in Mexico quadrangle (fig. 6). Wetlands also formed in former estuaries along Lake Ontario when the lake level rose in response to uplift of the St. Lawrence River outlet (Flint, 1971). Examples of estuary wetlands are Deer Creek marsh in Pulaski quadrangle, Butterfly swamp in Texas quadrangle, and Snake swamp in Oswego West quandrangle (fig. 6).

In the Tug Hill region, wetland formation has been categorized into six types (Jordan, 1978): intramorainal basins, basins related to stratified drift (such as those formed in kettle depressions), interdrumin basins, bedrock basins, meltwater-channel basins, and large wetland basins (either intramoraine or interdrumlin). The most extensive type of wetland in the Tug Hill region is the intramoraine basin; these wetlands occupy. isolated basins that formed between irregular ablation and recessional-moraine zones.

Alluvium.--Alluvium is significant only in the channel of the Salmon River in the reach from Altmar to Pulaski. In other streams, little alluvium has accumulated since postglacial time. Even along the county's largest waterway, the Oswego River, alluvial deposits are absent; this is attributed to gradual erosion.

\section{GROUND-WATER OCCURRENCE}

Ground water is available in most of the county and may be obtained from both bedrock and glacial deposits. Generally, larger water supplies can be obtained from sand and gravel deposits, less from bedrock, and the least from till or silt and clay deposits. Quantities obtainable from properly developed wells range from $0.25 \mathrm{gal} / \mathrm{min}$ in till or bedrock units to more than 1,000 $\mathrm{gal} / \mathrm{min}$ in outwash sand and gravel.

In unconsolidated deposits, water is stored in the openings (pore space) between particles. The amount of pore space (porosity) determines the amount of water that can be stored but not how much can be withdrawn. The amount of water that an aquifer releases from storage is called specific yield. Coarse, wellsorted material such as gravel has high porosity and high specific yield; mixed deposits such as silt, and gravel have low porosity and low specific yield, and well-sorted fine partikles such as clay have high porosity but low specific yield. 
The ground water is replenished by rain and snowmelt infiltrating through the soil to the saturated zone (water table) and moves downgradient from recharge areas to discharge areas such as streams, lakes, and wetlands. In recharge areas, annual water-level fluctuations are greater ( 5 to $25 \mathrm{ft}$ ) than in low discharge areas, where fluctuations are generally less than $10 \mathrm{ft}$.

The water table in unconsolidated deposits roughly parallels the land surface and is generally 5 to $30 \mathrm{ft}$ beneath it. The general direction of groundwater movement in bedrock is toward Lake Ontario (Kantrowitz, 1970). Table 1 (at end of report) presents well data and ground-water levels in selected wells.

\section{Bedrock}

The bedrock is made up of sedimentary rocks in which secondary cementation has closed most of the original intergranular pore space. The total volume of openings in such material seldom exceeds 5 percent. However, bedrock typically contains numerous fractures through which water can move freely, and wells tapping bedrock can draw water from these fractures.

Because fracturing generally decreases with depth, water is obtained principally from the upper levels of a bedrock unit. Fracturing, rather than rock type, is the controlling factor in the water-producing capacity of bedrock. Yields of bedrock wells range from 1 to $125 \mathrm{gal} / \mathrm{min}$, but most average $10 \mathrm{gal} / \mathrm{min}$. Most bedrock is overlain by relatively impermeable lodgment till, which acts as a confining layer, so that water. in bedrock is commonly under artesian pressure. Water levels in many wells penetrating bedrock rise above bedrock surface in response to water pressure in the formation. Bedrock units generally provide water adequate for domestic, small farm, and commercial use.

Regional ground-water flow in bedrock is northward to Lake Ontario. Recharge occurs from water infiltration through the overburden and possibly from ground water originating in the Finger Lakes region to the south. Ground water moving toward Lake Ontario becomes brackish as it dissolved materials from the rock, including salts of Silurian evaporite beds (Kantrowitz, 1970).

Chemical quality of water in bedrock depends on the depth of well penetration and rock type. Generally, ground water more than $100 \mathrm{ft}$ below land surface is brackish, whereas ground water above that depth is less mineralized.

In the upper $100 \mathrm{ft}$ of the Oswego Sandstone (figs. 4 and 5), the water is generally of suitable quality for drinking; water from the Queenston-Medina sequence contains some iron, and water from the Clinton Group contains salt, iron, and hydrogen sulfide.

\section{Lodgment Till}

Lodgment till, with its compactness and poorly sorted matrix of clay, silt, and sand surrounding pebble- to boulder-size material, has a low porosity and low specific yield and therefore does not yield water readily. However, these deposits can generally supply domestic and small farm needs if largediameter dug wells are installed. Dug wells are typically $3 \mathrm{ft}$ in diameter and 
10 to $20 \mathrm{ft}$ deep. Dug wells are successful because they provide a large surface area from which water may drain slowly from the till, and they also provide considerable storage capacity. Sustained yields of a dug well in lodgment till ranges from about 0.25 to $1 \mathrm{gal} / \mathrm{min}$., but, because of the well's large storage capacity, it can be pumped at 10 gal/min for about 30 minutes before becoming dry. It would take 5 to 20 hours for the well to refill.

Movement of water through lodgment till is slow. As an example, water in a till with a silty sand matrix could move about $3.6 \mathrm{ft} / \mathrm{yr}$. The velocity is estimated to be $0.01 \mathrm{ft} / \mathrm{d}$ from a hydraulic conductivity of $0.1 \mathrm{ft} / \mathrm{d}$, a hydraulic gradient of $3 \mathrm{ft}$ (vertical) per $100 \mathrm{ft}$ (horizontal), and a porosity of 0.3 . The water table in lodgment till roughly parallels land surface. Depth to water typically ranges from 5 to $20 \mathrm{ft}$.

\section{Ablation Till}

Ablation till is generally too thin and too impermeable to yield large quantities of water but, as a result of its higher sand content and less compact nature, it will yield slightly more water than lodgment till. Thickness typically ranges from 1 to $25 \mathrm{ft}$. Many areas of ablation till may be seasonally saturated. Ablation till provides sufficient water for domestic and small farm use, generally through dug wells.

\section{Lake Sediments}

Lake deposits are composed of sand, silt, and clay. Sand and silty sand are somewhat permeable and may yield low to moderate amounts of water to wells, but silt and clay are virtually impermeable and are the poorest aquifers in the county. Although silt and clay are porous, the stored water is held as a film by surface tension around the particles, so that water yield is low. In areas of silt and clay, wells must be drilled into an underlying, more permeable, unit such as bedrock.

Well-sorted sand having little or no silt could yield as much as 50 gal/min to wells. The higher the silt content, the poorer the yield. Lake deposits are prevalent in lowlands, where the water table is generally less than $10 \mathrm{ft}$ below land surface and undergoes annual fluctuations of less than $6 \mathrm{ft}$. Dug and drilled wells can yield water sufficient for domestic and farm use. Dug wells are typically constructed in the late summer or early fall, when water levels are lowest and wells can be dug the deepest.

Assuming a ground-water gradient common to lowlands of $1 \mathrm{ft}$ (vertical) to $100 \mathrm{ft}$ (horizontal) and a porosity of 35 percent, ground-water movement in fine sand is estimated to be $30 \mathrm{ft} / \mathrm{yr}$, and in clayey silt $0.001 \mathrm{ft} / \mathrm{yr}$.

\section{Aeolian Sand}

Sand dunes on the east side of former Lake Iroquois beach are either too thin to yield water or are above the water table, but they serve as recharge areas to the Lacona-Williamstown aquifer (fig. 2). Dunes along the eastern 
Ontario shore from Selkirk to North Pond (figs. 2, 6) yield moderate amounts of "water, but excessive withdrawal may induce water of poor quality from Lake Ontario or adjacent swamps.

\section{Wetlands}

Water from wetlands is typically unsuitable for drinking and domestic use because it may contain relatively high concentrations of iron and decaying organic material. However, wetlands play an important role in the environment by retaining pollutants, storing water during floods, and providing wildlife habitat. Wetlands are generally ground-water discharge areas, and the water level in wetlands commonly represents the water table.

\section{Sand and Gravel}

Sand and gravel deposits such as outwash, beaches, kame moraines, and esker-moraine complexes have the greatest potential for ground-water development. These deposits have high porosity and yield large amounts of water to properly constructed wells. Potential well yields range from 50 to 1,500 gal/min.

Most of the townships are underlain by some sand and gravel deposits. Deposits may be at land surface or partly or entirely buried beneath finegrained lacustrine deposits. The maximum thickness shown in well logs was 125 ft at Great Bear Farm in Pennellville quadrangle (fig. 6); elsewhere, average thickness is generally 25 to $50 \mathrm{ft}$. Thin deposits ( 5 to $25 \mathrm{ft}$ thick) in topographic highs are usually unsaturated or only seasonally saturated and are not reliable water sources. Useful sand and gravel aquifers are either in topographic lows or axe of sufficient thickness to extend tens of feet below the water table. The locations of potential sand and gravel aquifers in Oswego County are shown in figure 9.

The largest sand and gravel aquifer is a beach, outwash, and esker-kame moraine complex extending as a belt from the northern county border north of Lacona to the eastern boundary $2 \mathrm{mi}$ east of Williamstown (fig. 9). The LaconaWilliamstown aquifer is $20 \mathrm{mi}$ long and ranges in width from 0.5 to $3 \mathrm{mi}$. It is widest near Altmar. Thickness ranges from 10 to $85 \mathrm{ft}$.

The Lacona-Williamstown aquifer is tapped by three significant well fields; one is owned by the villages of Sandy Creek and Lacona, one by a paper company near Richland, and the other by a State fish hatchery near Altmar. Two wells $1.5 \mathrm{mi}$ north of Lacona (SC-5 and SC-7, table 1) supply Sand Creek and Lacona. These wells tap a beach deposit about $30 \mathrm{ft}$ thick; their yields are reported to range from 200 to 400 gal/min each.

The paper company's well field at Richland (fig. 6) taps beach and kame moraine deposits; the 12-inch diameter wells (Ri-11 and Ri-13, table 1) are reported to yield $800 \mathrm{gal} / \mathrm{min}$ each. Water levels during spring are generally 8 to $10 \mathrm{ft}$ below land surface and decline 25 to $30 \mathrm{ft}$ in late fall. Water quality meets U.S. Environmental Protection Agency drinking standards; hardness ranges from 100 to $200 \mathrm{mg} / \mathrm{L}$. 


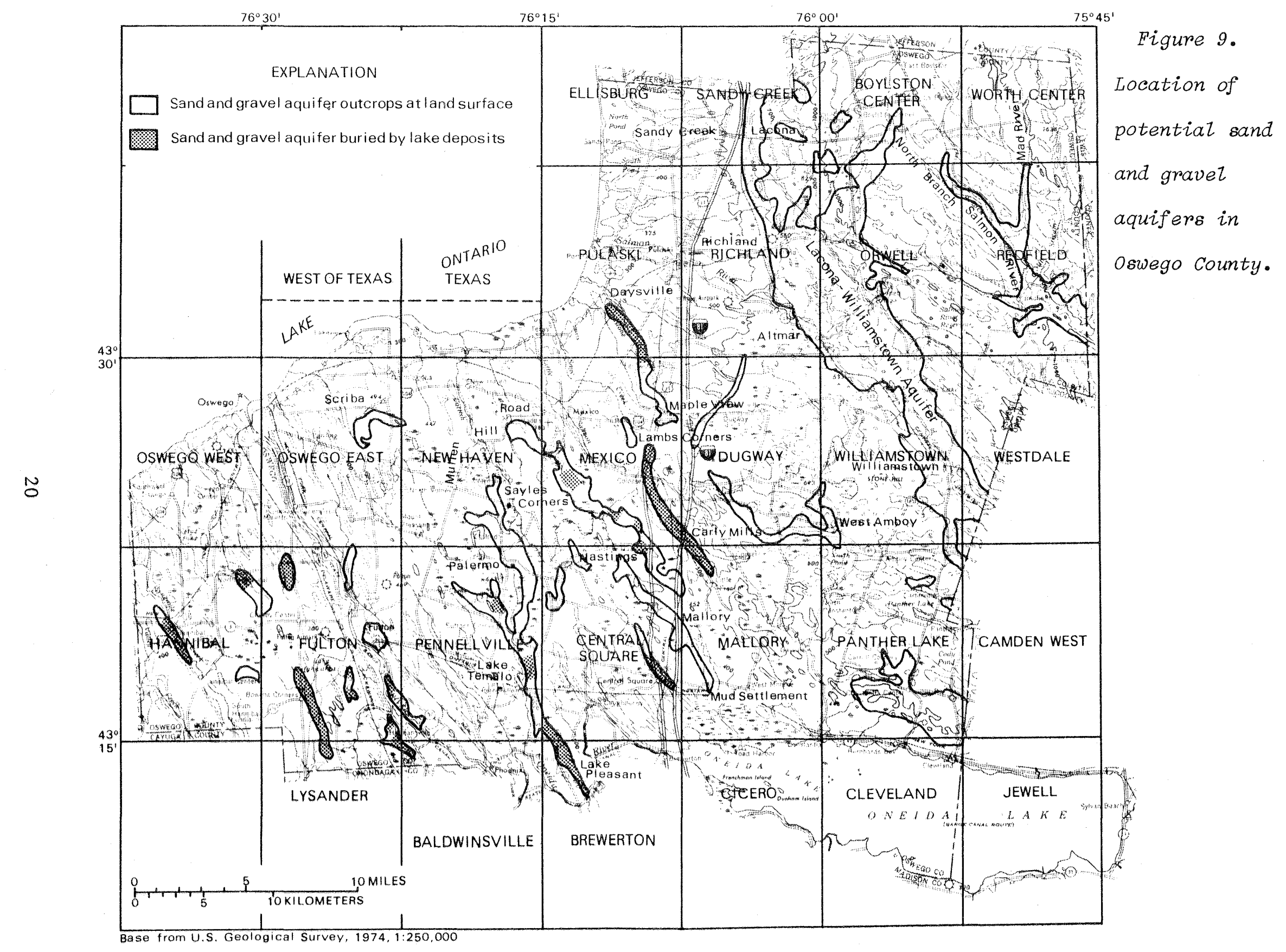


The State fish hatchery mear Altmar (fig.9) contains 25 test wells and severall prodiction wells that tap a kame moraine deposit. Sand and gravel ranges in thickmess from 30 to 85 ft and overlies bedrock and till. Results of five pumping tests (Irving, 1975) imdicate that specific capacity (rate of discharge from well per unit of drawdown) ramged from 5.5 to $30 \mathrm{gal} / \mathrm{min}$ per $\mathrm{ft}$ of drawdown, amd transmissivity (rate at which water flows through a unit width of the aquifer under a unit hydrawilic gradient) ranged from 60,000 to 100,000 (gal/d)/Et. Well yields ranged from 100 to $400 \mathrm{gal} / \mathrm{min}$.

The valley of the North Bramch Salmon River (fig. 9) contains an outwash deposit 6 mil long amdi about $0.25 \mathrm{mil}$ wide. This aquifer extends another $2 \mathrm{mi}$ eastward into Lewis County as a kame moraime plug in the Salmon River trough. The deposit is thickest where the Mad River, the largest ice margin channel of Oswego County, deposited its sediment load at the confluence of the North Branch Salmon River and Mad River valleys.

Areally extensive but thin (10 to $30 \mathrm{ft}$ thick) outwash aquifers line the west flank of the Tug Hill Plateau. These aquifers are common in Boylston Center, Richland, and Orwell quadrangles (fig. 6), but relatively little hydrologic data are available from these areas.

In the Tug Hill region, most beach and outwash aquifers are in hydraulic contact with streams, and a large percentage of water withdrawn from wells may be induced from these streams. As a result, the wells may be shallow and inexpensive to operate, but the quality of water from such wells is similar to that in the streams. The quality of ground water in the Tug Hill region is generally good. Results of 25 shallow ground-water samples collected and analyzed by U.S. Geological Survey, Oswego County Health Department, and engineering consultants revealed a range of hardness of 60 to $200 \mathrm{mg} / \mathrm{L}$, with $150 \mathrm{mg} / \mathrm{L}$ the average, and a range of chloride from 2 to $19 \mathrm{mg} / \mathrm{L}$, with $7 \mathrm{mg} / \mathrm{L}$ the average. Because the Tug Hill region is sparsely populated and virtually unindustrialized, the streams and ground water are not subject to significant contamination.

In the central and western part of the county, sand and gravel aquifers consist of kame and kame-esker deposits. Beach and wave-delta deposits in this region are generally unsuitable as aquifers because they are weakly developed or are on topographic highs above the water table. Except for a small area near Scriba (fig. 9), the region contains few outwash deposits because it was inundated by proglacial Lake Iroquois.

Discontinuous kame aquifers are common near Fulton and in the southern part of Fulton quadrangle (fig. 9). Lacustrine sand mantles some of the deposits so that their extent can be determined only from test drilling. Fulton obtains its water supply from kame deposits adjacent to Lake Neahtahwanta, along the east bank of the Oswego River, and at Great Bear Farm (fig. 6). Wells at Great Bear Farm range from 67 to $125 \mathrm{ft}$ in depth and yield 100 to $600 \mathrm{gal} / \mathrm{min}$ (Geraghty and Miller, 1967). Wells along the Oswego River south of Fulton are about $40 \mathrm{ft}$ deep and yield 200 to $400 \mathrm{gal} / \mathrm{min}$ (Barton, Brown, Clyde and Loguidice, 1967). Water levels and water quality at Great Bear Farm wells indicate that the Oswego River is far enough downgradient from pumping wells that river water is not induced into the wells. Chemical quality of water from the other wells close to the Oswego River (within $200 \mathrm{ft}$ ) suggests that the well field south of Fulton may be inducing recharge from the river. 
The central part of the county contains many small, irregularly distributed kame deposits. These are shown on the 7.5-minute quadrangles cited in the list of references but are too small to be plotted in figure 9. Small deposits may yield enough water for domestic, farm, and small municipal uses. The villages of Hannibal and Central Square obtain water from deposits of this type.

Several esker-kame deposits extend diagonally across central Oswego county from northwest to southeast (fig. 9; detailed maps showing the location of these deposits are cited in the list of references). The larger belts extend (1) from Sayles Corners through Palermo and through Lake Temalo to Lake Pleasant in Pennellville, Central Square, and Brewerton quadrangles; (2) from Mullen Hill Road at the east border of New Haven quadrangle past and 1.5 mi south of Mexico through Hastings and Mallory to Mud Settlement in Mallory quadrangle; (3) from Lamb's Corners through Carly Mills in Mexico and Mallory quadrangles; (4) from Daysville to Maple View in Pulaski and Mexico quadrangles; and (5) from Parish Center to West Amboy in Dugway and Williamstown quadrangles.

Most esker-kame deposits are poorly defined because they are partly covered by lacustrine deposits, are discontinuous, and have irregular physical characteristics such as varying thickness and width. Little hydrologic data on these deposits are available.

Several communities in Oswego County obtain water from the esker-kame deposits; among them are Phoenix, Mexico, and Central Square (fig. 9). Two Phoenix wells $(\mathrm{Br}-1$ and $\mathrm{Br}-2$, table 1), 1 mi northwest of Lake Pleasant, have reported yields of 700 and $400 \mathrm{gal} / \mathrm{min}$., respectively. Two Mexico wells, about $1.5 \mathrm{mi}$ south of the village, yield 225 and $340 \mathrm{gal} / \mathrm{min}$. The transmissivity of this aquifer is 80,000 (gal/d)/ft (Andrews, 1957).

\section{SUMMARY AND CONCLUSIONS}

Glacial sediments and marshes constitute most of the surface of Oswego County, which has few bedrock outcrops. Lodgment till in the form of drumlins and lake deposits is the most common type of deposit in the central and western part of the county; ablation till overlying lodgment till is the most common type on the Tug Hill Plateau. Extensive kame, outwash, and beach sand and gravel deposits are numerous along the west margin of the Tug Hill Plateau; sma11, patchy kame and beach deposits are common in the western and central regions. Bedrock consists of nearly flat-lying shale, siltstone, and sandstone.

The principal aquifers are kame, esker-kame, beach, and outwash deposits consisting of sand and gravel. Outwash aquifers are the most common type in the Tug Hill region, whereas kame, esker-kame, and beach aquifers predominate elsewhere. The largest sand and gravel aquifer is the Lacona-Williamstown aquifer, which is $20 \mathrm{mi}$ long, 0.5 to $3 \mathrm{mi}$ wide and 10 to $85 \mathrm{ft}$ thick, and yields from 200 to $800 \mathrm{gal} / \mathrm{min}$. 
Ground water is available everywhere in quantities generally sufficient

for domestic and farm use and, in some areas, in quantities sufficient for municipal and industrial supplies. Bedrock, lodgment till, ablation till, and lacustrine sand can yield sufficient quantities of water for farm and domestic use. In bedrock, the extent of fracture development rather than rock type is the major factor affecting water yield. Large-diameter dug wells are the only type that can obtain sufficient water from lodgment till, ablation til1, and lacustrine silty sand.

\section{SELECTED REFERENCES}

Andrews, Harry, 1957, Report of ground water investigation for village of Mexico, Oswego County, New York: Hall and Co., Delmar, N.Y., unpub. engineering rept., $7 \mathrm{p}$.

Barton, Brown, Clyde and Loguidice, Consulting Engineers, 1967, Oswego County water supply study: New York State Department of Health Contract CPWS-23, $111 \mathrm{p}$.

Broughton, J. G., Fisher, D. W., Isachsen, Y. W., and Rickard, L. V., 1962, The geology of New York State: New York State Museum and Science Service, Map and Chart Series 5, 42 p.

Flint, R. F., 1971, Glacial and quaternary geology: New York, John Wiley, 892 p.

Geraghty and Miller, 1967, Preliminary report of the ground-water resources at Great Bear Farm, Fulton, New York: Geraghty and Miller, Port Washington, N.Y., $11 \mathrm{p}$.

Irving, F. R., 1975, Test well program at proposed Great Lakes Fish Hatchery, Altmar, New York: New York State Department of Environmental Conservation, rept. D 90958, $13 \mathrm{p}$.

Isachsen, Y. W. and Fisher, D. W., 1970, Geologic map of New York, Adirondack sheet: New York State Museum and Science Service, Map and Chart Series 15.

Jordan, R. J., 1978, The deglaciation and consequent wetland formation of the Tug Hill Plateau, New York: Syracuse University, unpub. thesis, 110 p.

Jordan, R. J., and Miller, T. S., 1980, Surficial geology of Redfield quadrangle, Oswego County, New York: U.S. Geological Survey Water-Resources Investigations, Open-File Rept. 80-1118, 1 sheet.

Kantrowitz, I. H., 1970, Ground-water resources in the Eastern Oswego River basin, New York: New York State Department of Environmental Conservation, Basin Planning Rept. ORB-2, 129 p.

Miller, W. J., 1924, The geological history of New York State: New York State Museum and Science Bulletin 255, 148 p. 


\section{SELECTED PEPERENCES Tonthued}

Mi11er, T. S., 1981a, Surficial geology of Dugway quadrangle, Oswego County, New York: U.S. Geological Survey Water-Resources Investigations, Open-File Rept. 81-335, 1 sheet.

1980b, Surficial geology of Fulton quadrangle, Oswego County, New York: U.S. Geological Survey Water-Resources Investigations, Open-File Rept. $80-692,1$ sheet.

1981c, Surficial geology of Hamnal quadrangle, Oswego County, New Iork: U.S. Geological Survey Water-Resources Trvestigations, Open-File Rept. 81-129, 1 sheet.

1980d, Surficial geology of Malloxy quadrangle, Oswego County, New York: U.S. Geological Survey Watex-Resources Investigations, Open-File Rept. $81-336,1$ sheet.

, 1980e, Surficial geology of Orwell quadrangle, Oswego Councy, New York: U.S. Geological Suryey Wter-Resources Trvestigations, Open-File Rept. 80-1116, sheet.

, 1980f, Surficla geology of Oswego West quadrangle, Oswego County, Nen York: U.S. Geological Survey Waterwesounces Investigations, Open-File Rept. 30-968, 1 sheet.

-1980g, Surficial geology of part of Bolygton Center quadrangle, oswego County, New York: U.S. Geologlcal Survey Water-Resources Investigations, Open-F11e Rept. 80-1115, 1 sheet.

- 1981h, Surficial geology of paxt of Camden West quadrangle, Oswego County, New York: U.S. Geologlcal Survey Waterm Resources Investigations, Open-File Rept. 81-145, 1, sheet.

, 1980i, Surfelal geology of part of Ellisburg audrangle, Oswego County, New York: U.S. Geological Survey Water-Resources Investigations, Open-File Rept. 80m, 1 sheet.

, 1980j, Surficial geology of part of Sandy Creek quadrangle, Oswego County, New York: U.S. Geological Survey Water-Resources Investigations, Open-File Rept. 80-1114.

,1981k, Surficial geology of part of Westdale quadrangle, Oswego County, New York: U.S. Geological Survey Water-Resources Investigations, Open-File Rept. $81-147,1$ sheet.

,19801, Surficial geology of part of Worth Center quadrangle, Oswego County, New York: U.S. Geological Survey Water-Resources Investigations, Open-File Rept. 80-967, 1 sheet.

, 1981m, Surficial geology of Panther Lake quadrangle, Oswego County, New York: U.S. Geological Survey Water-Resources Investigations, Open-File Rept. 81-146, 1 sheet. 


\section{SELECTED REFERENCES (continued)}

,1980n, Surficial geology of Pennellville quadrangle, Oswego County, New

York: U.S. Geological Survey Water-Resources Investigations, Open-File

Rept. $80-411,1$ sheet.

,1980o, Surficial geology of Richland quadrangle, Oswego County, New

York: U.S. Geological Survey Water-Resources Investigations, Open-File Rept. $80-763,1$ sheet.

,1981p, Surficial geology of Williamstown quadrangle, Oswego County, New York: U.S. Geological Survey Water-Resources Investigations, Open-File Rept. $81-148,1$ sheet.

Miller, T. S., and Muller, E. H., 1979, Surficial geology of Pulaski quadrangle, Oswego County, New York: U.S. Geological Survey Water-Resources

Investigations, Open-File Rept. 1343, 1 sheet.

Muller, E. H., 1980a, Surficial geology of part of Baldwinsville quadrangle, Oswego County, New York: U.S. Geological Survey Water-Resources

Investigations, Open-File Rept. $80-405,1$ sheet.

,1980b, Surficial geology of part of Brewerton quadrangle, Oswego County, New York: U.S. Geological Survey Water-Resources Investigations, Open-File Rept. 80-402, 1 sheet.

,1980c, Surficial geology of part of Cicero quadrangle, Oswego County, New York: U.S. Geological Survey Water-Resources Investigations, Open-File Rept. 80-761, 1 sheet.

,1980d, Surficial geology of West of Texas quadrangle, Oswego County, New York, U.S. Geological Survey Water-Resources Investigations, Open-File Rept. $80-1113,1$ sheet.

Muller, E. H., Jordan, R. J., and Miller, T. S., 1980, Surficial geology of Mexico quadrangle, Oswego County, New York: U.S. Geological Survey Water-Resources Investigations, Open-File Rept. 80-2040, 1 sheet.

Muller, E. H., and Miller, T. S., 1980a, Surficial gẹology of Central Square quadrangle, Oswego County, New York: U.S. Geological Survey Water-Resources Investigations, Open-File Rept. 80-2039, 1 sheet.

,1980b, Surficial geology of New Haven quadrangle, Oswego County, New York: U.S. Geological Survey Water Resources Investigations, Open-File Rept. $80-1208,1$ sheet.

,1980c, Surficial geology of Oswego East quadrangle, Oswego County, New York: U.S. Geological Survey Water-Resources Investigations, Open-File Rept. $80-1209,1$ sheet.

,1980d, Surficial geology of part of Cleveland quadrangle, Oswego County,. New York: U.S. Geological Survey Water-Resources Investigations, Open-File Rept. 80-762, 1 sheet. 


\section{SELECTED REFERENCES (continued)}

,1980e, Surficial geology of part of Lysander quadrangle, Oswego County, New York: U.S. Geological Survey Water-Resources Investigations, Open-File Rept. 80-1117, 1 sheet.

,1980f, Surficial geology of Texas quadrangle, Oswego County, New York: U. S. Geological Survey Water-Resources Tnvestigations, Open-File Rept. $80-760,1$ sheet.

Patchen, D. G., 1978, Depositional environments of the Oswego sandstone (Upper Ordovician), Oswego County, New York: New York State Geological Association Guidebook, 50th Annual Meeting, Syracuse, N.Y., p. 368-385.

Rickard, L. V., and Fisher, D. W., 1970, Geologic map of New York, Finger Lakes sheet: New York State Museum and Science Service, map and chart series 15.

Soloman, N. L., 1974, Stratigraphy of glacial deposits along the south shore of Lake Ontario, New York: Syracuse, N.Y., Syracuse University, unpub. Masters" thesis, $77 \mathrm{p}$.

Sutton, R. G., Lewis, T. L., and Woodrow, D. L., 1972, Post-Iroquois lake stages and shoreline sedimentation in eastern ontario basin: Journal of Geology, v. 80, p. $346-356$.

Wright, F. M. 1973, The Pleistocene and recent geology of the Oneida-Rome district, New York: Syracuse University, unpub. doctoral dissertation, $191 \mathrm{p}$. 
TABLE 1

Data on selected wells in Oswego County, New York

[Locations are shown on next page]

EXPLANATTON

Each well has a county number and a U.S. Geological Survey number. County numbers indicate well location by quadrangle; for example, wells in Boylston Center quadrangle are designated $B C-1, B C-2$, etc., and wells in Ellisburg quadrangle are designated E1-1, E1-2, etc. Geological Survey numbers are based on latitude and longitude to facilitate retrieval of computer data. Because the entire county is within latitude $42^{\circ}$ and $43^{\circ}$ and longitude $75^{\circ}$ and $77^{\circ}$, the digits 4 and 7 are omitted, and location is indicated by the second digit of the degree and the two digits of minutes. Wells within each 1-minute rectangle are numbered consecutively in the order in which they were inventoried. For example, we11 318-603-1 is at $43^{\circ} 18^{\prime}$ lat. and $76^{\circ} 03^{\prime}$ long. and was the first well inventoried within that 1 -minute rectangle. 
$76^{\circ} 30^{\prime}$

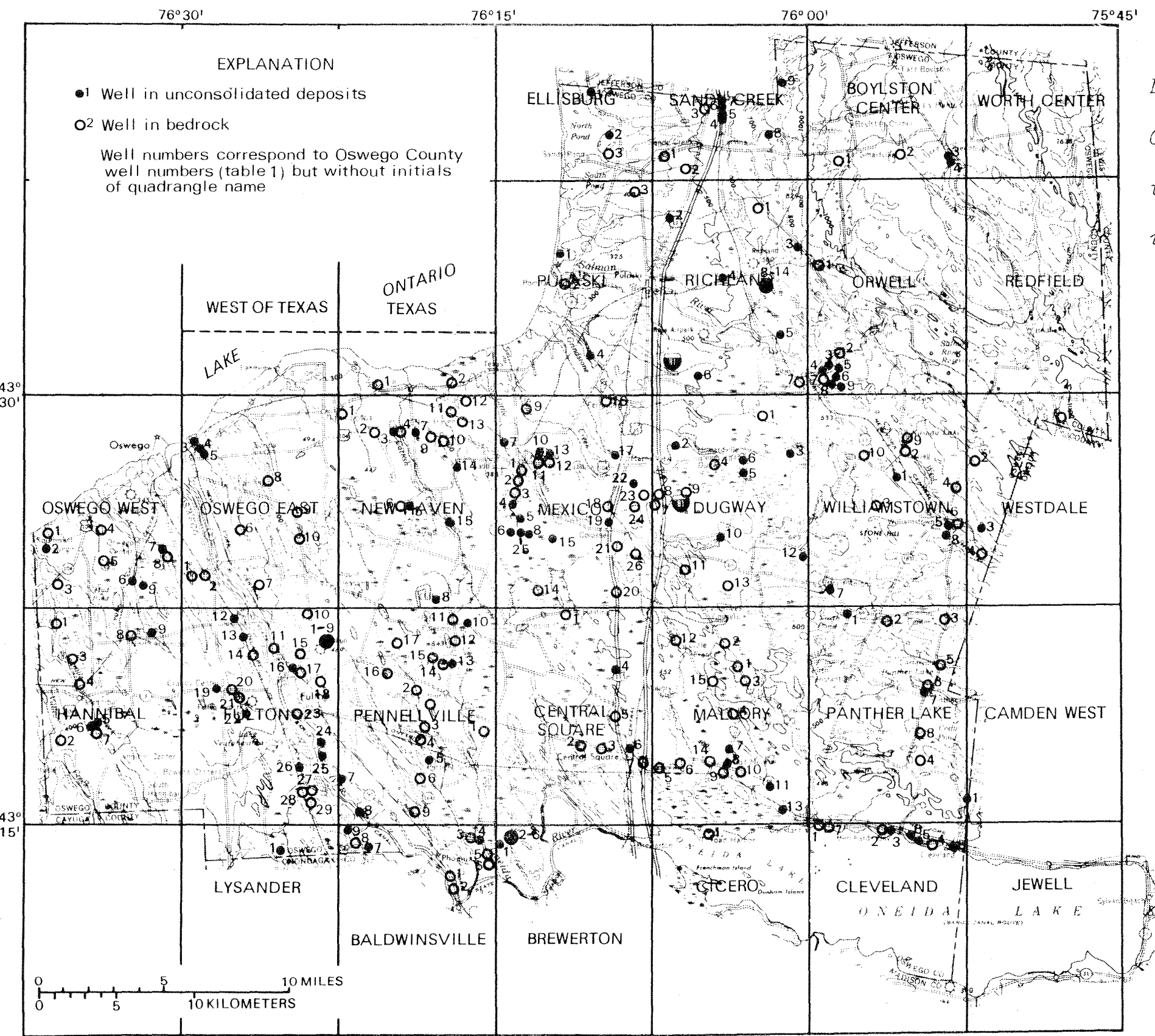

Figure 10.

Location of Oswego County wells and test holes listed in table 1. 
FOOTNOTES TO TABLE 1

\section{Type of we11:

Drl $=$ drilled
Dug $=$ dug
Drv $=$ driven

\section{Altitude:}

in feet above Nationa 1 Geodetic Vertical Datum of 1919 (NGVD), estimated from topographic maps.
2. Aquifer type

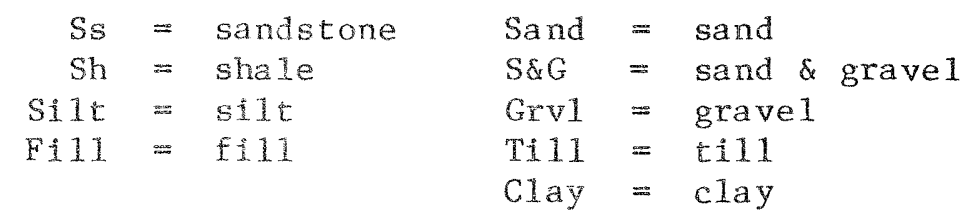

4. Water Use
$A$ abandoned
$I$ = industrial
$c=$ commertcal
D = domestic
$\mathrm{PS}=$ public supply
In = institutional
$T=$ test
$0=$ observation
$\mathrm{U}=$ unused

5. Remarks
H2S = noticeable odor of hydrogen sulfide

hard = occupant reports hard water

$\mathrm{Fe}=$ water contains relatively high concentration of iron and commonly stains porcelain fixtures 
Table 1.-Data on Selected Wells in Oswego County (Continued)

[Locations are given in fig. 10; depths are in feet below National Geodetic Vertical Datum of 1929]

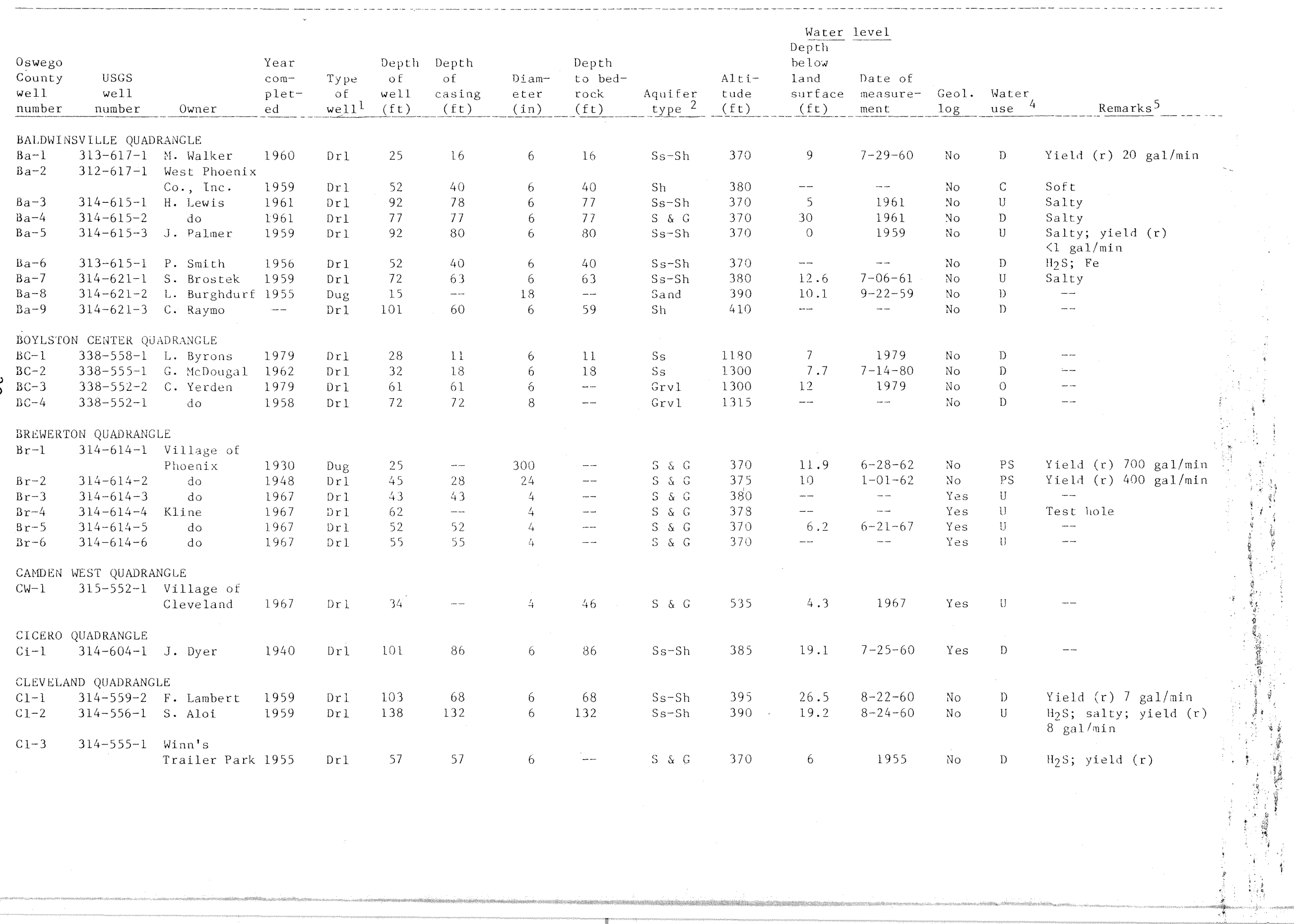




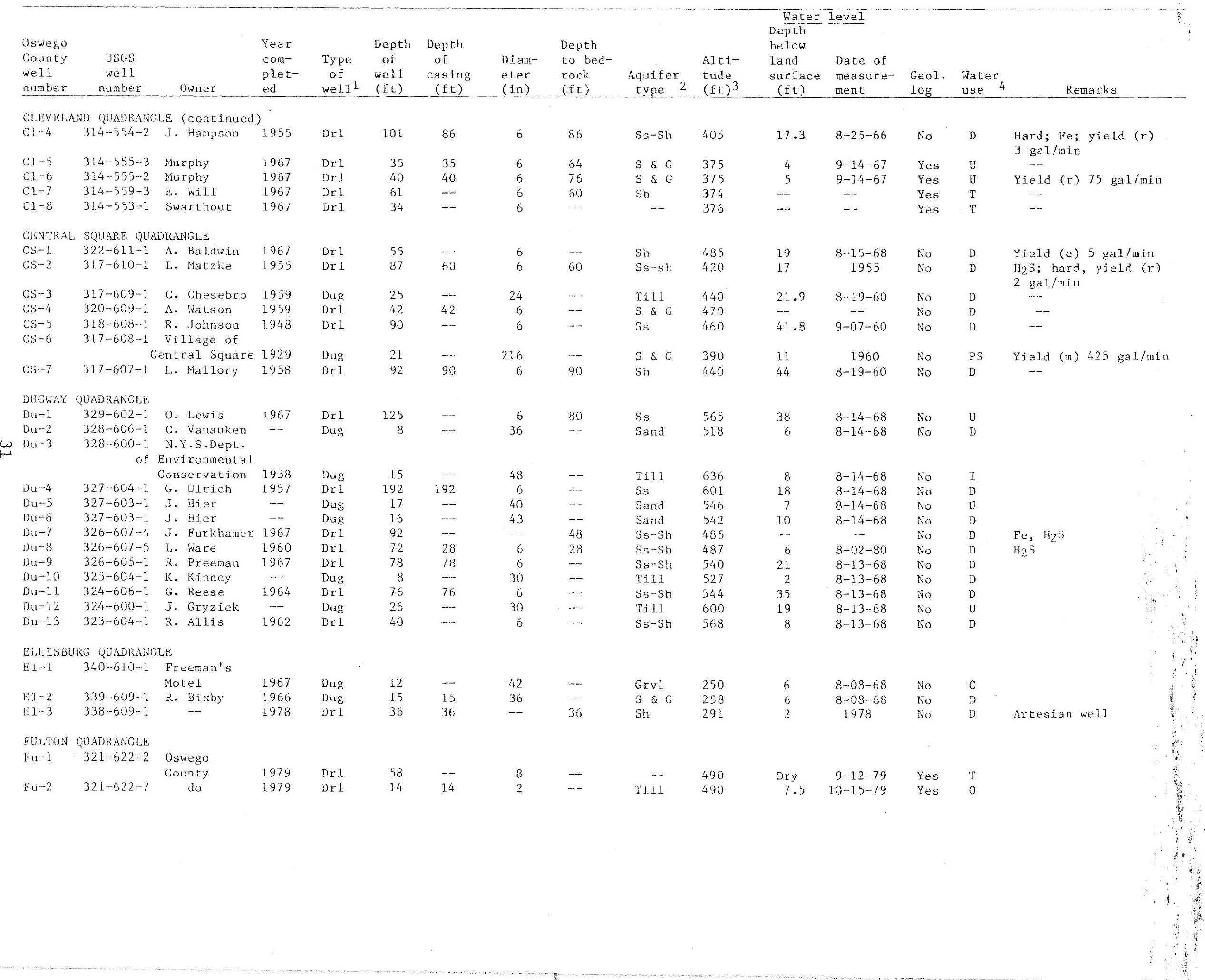


Table 1.- Data on Selected Wells in Oswega County (Continued)

[Locations are given in fig. 10; depths are in feet below National Geodetic Vertical Datum of 1929]

\begin{tabular}{|c|c|c|c|c|c|c|c|c|c|c|c|c|c|c|c|}
\hline $\begin{array}{l}\text { Oswego } \\
\text { County } \\
\text { wel1 } \\
\text { number }\end{array}$ & $\begin{array}{c}\text { USGS } \\
\text { we11 } \\
\text { number }\end{array}$ & Owner & $\begin{array}{l}\text { Year } \\
\text { comm- } \\
\text { plet- } \\
\text { ed }\end{array}$ & $\begin{array}{c}\text { Type } \\
\text { of } \\
\text { we11 } 1\end{array}$ & $\begin{array}{c}\text { Depth } \\
\text { of } \\
\text { well } \\
\text { (ft) }\end{array}$ & $\begin{array}{l}\text { Depth } \\
\text { of } \\
\text { casing } \\
\text { (ft) }\end{array}$ & $\begin{array}{l}\text { Diam- } \\
\text { eter } \\
\text { (in) }\end{array}$ & $\begin{array}{l}\text { Depth } \\
\text { to bed- } \\
\text { rock } \\
\text { (ft) }\end{array}$ & $\begin{array}{l}\text { Aquifer } \\
\text { type }\end{array}$ & $\begin{array}{l}\text { Alti- } \\
\text { tude } \\
(f t)\end{array}$ & $\begin{array}{l}\text { Depth } \\
\text { below } \\
\text { land } \\
\text { surface } \\
\text { (ft) }\end{array}$ & $\begin{array}{l}\text { Date of } \\
\text { measure- } \\
\text { ment }\end{array}$ & $\begin{array}{l}\text { Geol. } \\
\text { log }\end{array}$ & $\begin{array}{l}\text { Water } \\
\text { use } 4\end{array}$ & Remarks 5 \\
\hline \multicolumn{16}{|c|}{ HANNIBAT QUADRANGLE } \\
\hline $\mathrm{Ha}-1$ & $322-636-1$ & E. Ha11 & 1966 & Drl & 2559 & 124 & 9 & $\cdots$ & -- & 310 & -- & -- & Yes & $\mathrm{U}$ & Wildcat well \\
\hline $\mathrm{Ha}-2$ & $318-635-1$ & Adamy & 1979 & Drl & 95 & 55 & 6 & 55 & Ss & 365 & 30 & $6-02-79$ & Yes & D & Yield (r) $5 \mathrm{gal} / \mathrm{min}$ \\
\hline $\mathrm{Ha}-3$ & $320-634-1$ & Draper & 1979 & Drl & 100 & 60 & 6 & 60 & Ss & 4.85 & 25 & $7-10-79$ & Yes & D & Yield (r) $2 \mathrm{gal} / \mathrm{min}$ \\
\hline $\mathrm{Ha}-4$ & $319-634-1$ & Pitchard & 1979 & $D_{1} \cdot 1$ & 42 & 30 & 6 & 30 & $5 s$ & 340 & 10 & 1979 & Yes & D & Yield (x) $30 \mathrm{gal} / \mathrm{min}$ \\
\hline $\mathrm{Ha}-5$ & $318-634-1$ & $\mathrm{H}$. Hendricks & 1967 & Dri & 28 & $\cdots$ & 6 & 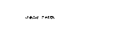 & $\mathrm{S} \mathrm{G}$ & 325 & 15.3 & 1967 & Yes & U & \\
\hline $\mathrm{Ha}-6$ & $318-634-2$ & do & 1967 & Dr1 & 23 & $\ldots-$ & 6 & $m-$ & 869 & 328 & 15.2 & 1967 & Yes & U & \\
\hline $\mathrm{Ha}-7$ & $318-634-3$ & D. Cooper & 1978 & Dri & 62 & 40 & 6 & 40 & ss-sh & 340 & 15 & $5-10-80$ & Yes & $\mathrm{D}$ & Yield (r) $8 \mathrm{ga} 1 / \mathrm{min}$ \\
\hline $\mathrm{Ha}-8$ & $321-631-1$ & M. Kranz & 1952 & Dr1 1 & 41.5 & 18 & 8 & 18 & Sh & 350 & 5.5 & $5-29-80$ & No & D & Hard; some iron \\
\hline $\mathrm{Ha}-9$ & $321-630-1$ & C. Scruton & 1960 & Dri & 80 & 80 & 8 & $-\infty$ & Grv1 & 339 & $-\cdots$ & -- & No & D & \\
\hline $\mathrm{Ha}-10$ & $320-630-1$ & M. Benedict & 1971 & Dr 1 & 54 & $\cdots$ & $\cdots$ & -- & $8 s-5 t$ & 438 & 26 & $8-12-80$ & No & $\mathrm{D}$ & \\
\hline \multicolumn{16}{|c|}{ LYSANDER QUADRANGLE } \\
\hline$L y-1$ & $313-625-1$ & & 1976 & Dr1 & 102 & 77 & $-\cdots+$ & 77 & Sh & 395 & 87 & $-\infty$ & No & D & Yield (e) $40 \mathrm{gal} / \mathrm{min}$ \\
\hline \multicolumn{16}{|c|}{ MALLORY QUADRANGLE } \\
\hline $\mathrm{Ma}-1$ & $320-603-1$ & D. Calella & 1959 & Dr1 & 37 & 10 & 6 & 10 & Ss & 530 & 13.2 & $7-25-60$ & No & D & \\
\hline $\mathrm{Ma}-2$ & $320-603-2$ & J. O' Donnel1 & 1959 & Dug & 17 & $-\cdots$ & 20 & $\ldots$ & Yiti & 510 & 15.6 & $7-25-60$ & No & D & \\
\hline $\mathrm{Ma}-3$ & $319-602-1$ & F. Fisher & 1957 & Drl & 36 & 20 & 6 & 20 & $\mathrm{Se}$ & 490 & 16 & .1957 & No & $D, S$ & \\
\hline $\mathrm{Ma}-4$ & $318-603-1$ & C. York & 1959 & Drl & 42 & 38 & 6 & 38 & So & 490 & 4.6 & $7-21-60$ & No & $\mathrm{D}$ & \\
\hline $\mathrm{Ma}-5$ & $317-606-1$ & W. Devendorf & 1955 & Dri & 62 & 62 & 6 & $\ldots$ & $8 \& 6$ & 420 & 10.4 & $8-19-60$ & No & D & Yield (r) $15 \mathrm{gal} / \mathrm{min}$ \\
\hline$M a-6$ & $317-606-2$ & C. Spooner & 1943 & Dni & 43 & 43 & 5 & $-\infty$ & $S \& G$ & 410 & 25 & 1950 & No & $D, S$ & Yield $(r)>30 \mathrm{gal} / \mathrm{min}$ \\
\hline Ma-7 & $317-603-1$ & J. Cunningham & $n 1957$ & $\operatorname{Dr} 1$ & 92 & 92 & 6 & $-\cdots$ & $5 \% 6$ & 455 & 29.1 & $7-25-60$ & & & \\
\hline $\mathrm{Ma}-8$ & $416-604-1$ & J. Saver & 1945 & $D \times 1$ & 22 & $\cdots$ & 6 & $\ldots$ & $s: 6$ & 400 & 7.7 & $7-25-60$ & No & D & $\mathrm{Cl}=8 \mathrm{mg} / \mathrm{L}, 7-25-60$ \\
\hline $\mathrm{Ma}-9$ & $316-604-2$ & E. Guiles & 1954 & DrI & 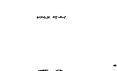 & 52 & 6 & 52 & So & 395 & 6.8 & $8-22-50$ & No & D & $\begin{array}{l}\text { SaIty, cl=475 mg/L, } \\
8-24-60\end{array}$ \\
\hline $\mathrm{Ma}-10$ & $316-602-1$ & K. Payes & 1955 & DrI & 78 & 55 & 6 & 55 & So & 460 & 36.9 & $8-24-60$ & No & $D, S$ & $\mathrm{H}_{2} \mathrm{~S}$, yield $(\mathrm{r}) 10 \mathrm{gar} / \mathrm{m}$ \\
\hline Ma-11 & $316-601-1$ & L. Kukko & 1959 & Dug & 15 & $\cdots$ & 36 & - & Thi & 448 & 11.2 & $8-22-60$ & No & D & 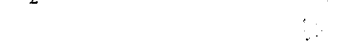 \\
\hline \multirow{2}{*}{$\mathrm{Ma}-13$} & $\begin{array}{l}321-606-1 \\
315-601-1\end{array}$ & $\begin{array}{l}R \text {. Donegan } \\
\text { Constantia }\end{array}$ & 1975 & Drl & 60 & 60 & 6 & $-\cdots$ & Sand & 505 & 4 & 1975 & No & D & \\
\hline & & School & 1945 & Dre 1 & 80 & $\ldots . . .$. & 6 & $\ldots$ & $E \& G$ & 440 & 11 & $8-26-60$ & No & I & $\mathrm{Cl}=50 \mathrm{mg} / \mathrm{L}, 8-24-60$. \\
\hline $\mathrm{Ma}-14$ & $317-604-1$ & A. Green & 1945 & Dr 1 & 91 & 1 & 6 & 90 & Ss $-\operatorname{sh}$ & 425 & 22 & 1945 & No & $\mathrm{D}, \mathrm{S}$ & 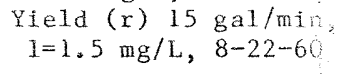 \\
\hline $\mathrm{Ma}-15$ & $319-604-1$ & H. Bean & 1975 & Dri & 120 & 75 & 6 & 75 & $S s-3 h$ & 525 & $-\infty$ & -- & No & D & \\
\hline \multicolumn{16}{|c|}{ MEXICO QUADRANGLE } \\
\hline \multirow[t]{2}{*}{$\mathrm{Me}^{-1}$} & $327-613-1$ & Village of & & & & & & & & & & & & & \\
\hline & & Mexico & 1957 & Dr1 & 17 & $\ldots$ & $\ldots$ & 17 & $\cdots$ & 375 & $\cdots$ & -- & Yes & $\mathrm{U}$ & Test hole \\
\hline $\mathrm{Me}-2$ & $327-613-2$ & do & 1957 & Dr1 & 18 & $\ldots$ & 8 & 18 & .... & 368 & $\cdots$ & -- & Yes & $\mathrm{U}$ & \\
\hline $\mathrm{Me}-3$ & $326-613-1$ & do & 1957 & Dr1 & 9 & $\cdots$ & 8 & 9 & 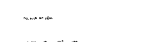 & 393 & $-\ldots$ & -- & Yes & U & 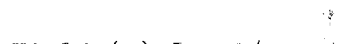 \\
\hline $\mathrm{Me}-4$ & $326-613-2$ & do & 1957 & Dri & 27 & $\cdots$ & 8 & 27 & Til & 405 & - & $-\infty$ & Yes & $\mathrm{U}$ & Yield (m) $5 \mathrm{gal} / \mathrm{min}$ \\
\hline $\mathrm{Me}-5$ & $325-613-1$ & do & 1957 & Dr1 & 21 & $-\cdots$ & 8 & 21 & Grvidelay & 409 & $-\cdots$ & -- & Yes & u & Yield (m) $3 \mathrm{gal} / \mathrm{min}$ \\
\hline
\end{tabular}




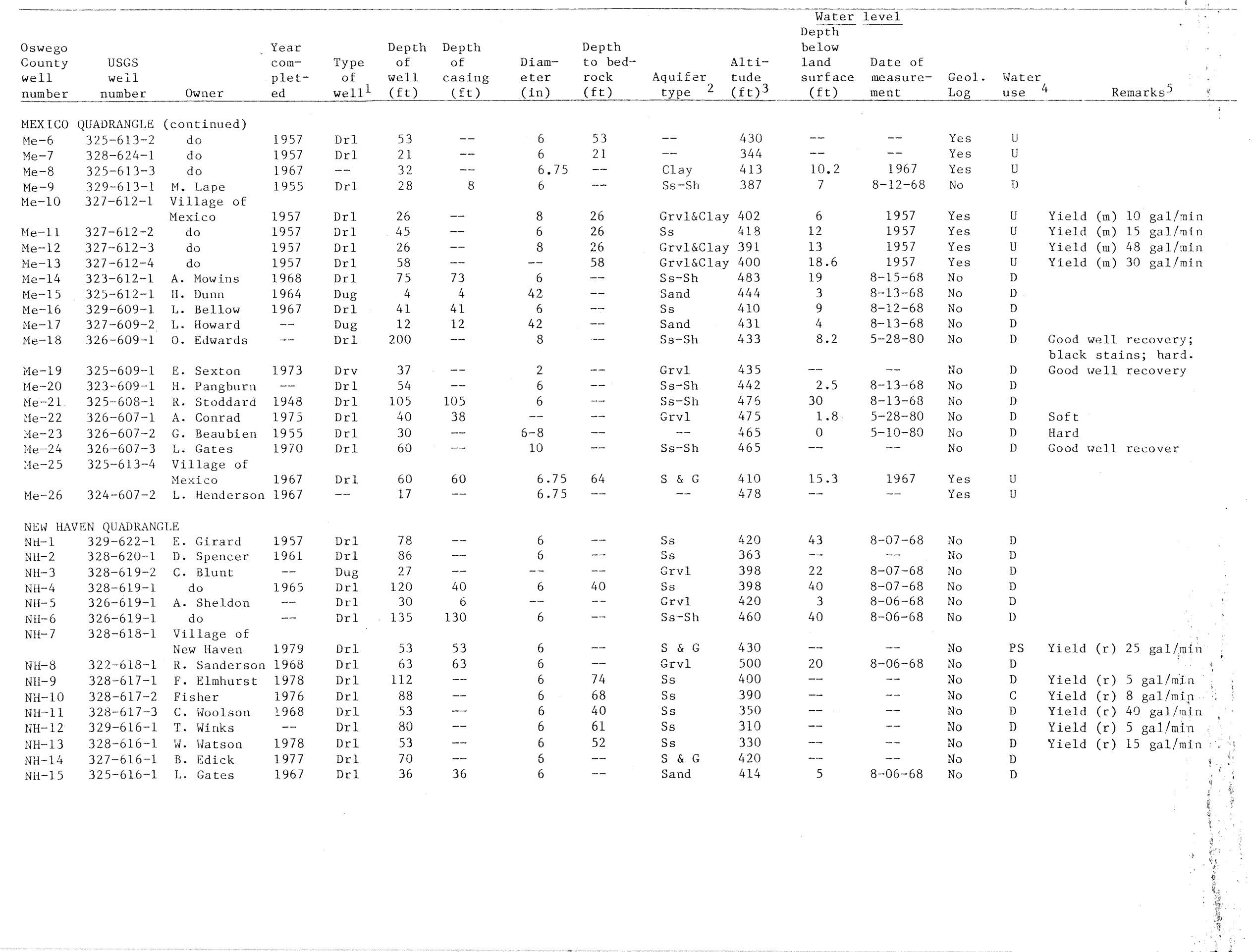


Table 1.--Data on Selected Wells in Oswego Courty (Continued)

[Locations are given in fig. 10; depths are in feet below National Geodetic Vertical Datum of 1929]

\begin{tabular}{|c|c|c|c|c|c|c|c|c|c|c|c|c|c|c|c|}
\hline $\begin{array}{l}\text { Oswego } \\
\text { County } \\
\text { well } \\
\text { number } \\
\end{array}$ & $\begin{array}{c}\begin{array}{c}\text { USGS } \\
\text { we11 } \\
\text { number }\end{array} \\
\end{array}$ & Owner & $\begin{array}{l}\text { Year } \\
\text { com- } \\
\text { plet- } \\
\text { ed }\end{array}$ & $\begin{array}{c}\text { Type } \\
\text { of } \\
\text { we1 } 11 \\
\end{array}$ & $\begin{array}{l}\text { Depth } \\
\text { of } \\
\text { well } \\
\text { (ft) }\end{array}$ & $\begin{array}{l}\text { Depth } \\
\text { of } \\
\text { casing } \\
\text { (ft) }\end{array}$ & $\begin{array}{l}\text { Diam- } \\
\text { eter } \\
\text { (in) }\end{array}$ & $\begin{array}{l}\text { Depth } \\
\text { to bed- } \\
\text { rock } \\
(\mathrm{ft})\end{array}$ & $\begin{array}{l}\text { Aquifer } \\
\text { type } 2\end{array}$ & $\begin{array}{l}\text { Alti- } \\
\text { tude } \\
(\mathrm{ft})^{3}\end{array}$ & $\begin{array}{l}\text { Water } \\
\text { Depth } \\
\text { below } \\
\text { land } \\
\text { surface } \\
\text { (ft) }\end{array}$ & $\begin{array}{l}\text { Date of } \\
\text { measure- } \\
\text { ment }\end{array}$ & $\begin{array}{l}\text { Geol. } \\
\text { log }\end{array}$ & $\begin{array}{l}\text { Water } \\
\text { use } 4\end{array}$ & Remarks 5 \\
\hline OSWEGO & EAST QUADRA & ANGLE & & & & & & & & & & & & & \\
\hline $\mathrm{CE}-1$ & $324-629-1$ & A. Mangano & 1950 & Dr1 & 57 & 54 & 6 & 54 & Ss & 350 & 24.3 & $8-02-60$ & No & $\mathrm{D}$ & Yield (r) $4 \mathrm{gal} / \mathrm{min}$ \\
\hline $\mathrm{OE}-2$ & $324-628-1$ & J. Castigalia & a1959 & Dr1 & 208 & 70 & 6 & 70 & Ss & 330 & 40 & 1959 & No & $\mathrm{U}$ & Sa1ty \\
\hline $\mathrm{OE}-3$ & PAS-1a & City of & & & & & & & & & & & & & \\
\hline$O E-4$ & PAS-3 & $\begin{array}{l}\text { Oswego } \\
\text { Pollution }\end{array}$ & 1979 & Dr1 & 9.5 & 7.0 & 2 & 11 & Fill & 260 & 6.3 & $10-15-79$ & Yes & $\mathrm{U}$ & \\
\hline$O E-5$ & $\begin{array}{l}\text { Abate } \\
\text { PAS-11a }\end{array}$ & $\begin{array}{l}\text { ement Service } \\
\text { City of }\end{array}$ & 1979 & Dr1 & 13 & 10.5 & 2 & - & s & 273 & .6 & $10-15-79$ & Yes & $\mathrm{U}$ & \\
\hline & & Oswego & 1980 & Dr1 & 10.25 & 7.4 & 2 & -- & Till & 280 & 5.7 & $4-22-80$ & Yes & $\mathrm{u}$ & \\
\hline$O E-6$ & $325-627-1$ & Santoro & 1979 & Dr1 & 95 & 45 & 6 & 44 & Ss & 399 & 35 & $6-01-79$ & Yes & D & Yield (r) 3 gal/min \\
\hline $\mathrm{OE}-7$ & $323-626-1$ & Bellinger & 1980 & Dr1 & 87 & 30 & 6 & 30 & Ss & 419 & 35 & $4-10-80$ & Yes & D & Yield (r) $2 \mathrm{gal} / \mathrm{min}$ \\
\hline $\mathrm{OE}-8$ & $327-625-1$ & D. LaF ave & 1979 & $\operatorname{Dr} 1$ & 99 & 99 & 6 & 76 & sis & 410 & - & -- & Yes & D & Yield (r) $1.5 \mathrm{ga} 1 / \mathrm{min}$ \\
\hline$O E-9$ & $325-624-1$ & R. Burdick & 1.956 & Dr1 & 65 & 40 & 6 & 40 & Ss & 460 & $\cdots$ & -- & No & D & Yield (r) $10 \mathrm{gal} / \mathrm{nin}$ \\
\hline $\mathrm{OE}-10$ & $324-624-1$ & S. Mistretta & 1952 & $\operatorname{Dr} 1$ & 117 & 30 & 6 & 30 & Ss & 400 & - & -- & No & D & Yield (e) 1 gal/min \\
\hline ORWELL & QUADRANGLE & & & & & & & & & & & & & & \\
\hline Or-1 & $334-559-1$ & E. Pizon & 1967 & Dr1 & 136 & 100 & 6 & 100 & Ss & 870 & 54 & $8-14-68$ & No & D & \\
\hline $0 r-2$ & $\begin{array}{r}331-558-2 \\
\text { of }\end{array}$ & $\begin{array}{l}\text { N.Y.S.Dept. } \\
\text { Environmenta1 }\end{array}$ & & & & & & & & & & & & & \\
\hline & & Conservation & 1974 & DrI & 40 & 37 & 6 & 36 & Ss & 597 & 10 & $10-24-74$ & Yes & $\mathrm{T}$ & Yield (m) $50 \mathrm{gal} / \mathrm{min}$ \\
\hline or -3 & $330-559-2$ & Do & 1974 & DrI & 43 & 43 & 8 & 44 & $S \& G$ & 572 & 8.1 & $1-08-75$ & Yes & In & Production well \\
\hline $0 r-4$ & $330-559-1$ & Do & 1974 & Dr1 & 42 & 42 & 6 & 40 & $S S-S \& Q$ & 555 & 1.0 & $11-06-74$ & Yes & $\mathrm{T}$ & \\
\hline or -5 & $330-559-3$ & Do & 1974 & $\operatorname{Drl}$ & 53 & 53 & 6 & -- & $S \& G$ & 571 & 7.4 & $10-29-74$ & Yes & 0 & $\begin{array}{l}\text { Yield (m) } 150 \mathrm{gal} / \mathrm{rain} \\
\text { from open end }\end{array}$ \\
\hline $0 x^{-6}$ & $330-559-4$ & Do & 1974 & Drl & 53 & 53 & 12 & -- & $S \& G$ & 572 & 8.2 & $11-12-74$ & Yes & 0 & Yield (m) $460 \mathrm{gal} / \mathrm{min}$ \\
\hline Or-7 & $330-559-5$ & Do & 1974 & Dr1 & 75 & 57 & 3 & 52 & Ss & 568 & 2.6 & $11-14-74$ & Yes & In & $\begin{array}{l}\text { Production well, } \\
\text { yield (m) } 280 \mathrm{gal} / \mathrm{min}\end{array}$ \\
\hline Or-8 & $330-559-6$ & Do & 1974 & Drl & 33 & 33 & 8 & 33 & $S \& G$ & 574 & 5.6 & $1-08-75$ & Yes & In & $\begin{array}{l}\text { Production well, } \\
\text { yield (m) } 303 \mathrm{gal} / \mathrm{min}\end{array}$ \\
\hline $0 r-9$ & $330-558-1$ & Do & 1974 & Dr1 & 84 & 84 & 3 & $\cdots$ & $S \& G$ & 611 & 26.6 & $12-17-74$ & Yes & In & $\begin{array}{l}\text { Production well, } \\
\text { yield (m) } 367 \text { gal/min }\end{array}$ \\
\hline OSWEGO & WEST QUADRA & ANGLE & & & & & & & & & & & & & \\
\hline OW-1 & $325-636-1$ & P. Weber & 1973 & Dr1 & 120 & -- & $-\cdots$ & - & Ss & 310 & - & $\rightarrow$ & No & $\mathrm{D}$ & Yield (e) 2 gal/rain \\
\hline ow-2 & $324-636-1$ & C. Groat & -- & Dug & 36 & - & -- & $-\infty$ & Till & 326 & 8 & $6-04-80$ & No & $\mathrm{D}$ & Hard \\
\hline ow -3 & $323-636-1$ & M. Stock & 1968 & Dr1 & 156 & 156 & 6 & 156 & $\mathrm{Sh}$ & 345 & - & -- & No & D & $\begin{array}{l}\mathrm{H}_{2} \mathrm{~S} ; \text { yield }(\mathrm{r}) \\
0.5 \mathrm{gal} / \mathrm{min}\end{array}$ \\
\hline$O W-4$ & $325-633-1$ & D. Geers & 1963 & Drl & 95 & 95 & - & -- & Sh & 355 & - & -- & No & $\mathrm{D}$ & Hard; $\mathrm{H}_{2} \mathrm{~S}$ \\
\hline ow -5 & $324-633-1$ & R. Brooker & 1968 & Dr1 & 101 & $\cdots$ & - & $\rightarrow$ & Ss & 365 & - & - & No & $\mathrm{D}$ & $\begin{array}{l}\mathrm{H}_{2} \mathrm{~S} ; \text { yield }(\mathrm{r}) \\
13 \mathrm{gal} / \mathrm{min}\end{array}$ \\
\hline $0 w-6$ & $323-631-1$ & M. Allen & -- & Dug & 30 & -- & -- & 30 & Ti111 & 348 & 8.4 & $5-29-80$ & No & D & Hard \\
\hline
\end{tabular}




\begin{tabular}{|c|c|c|c|c|c|c|c|c|c|c|c|c|c|c|c|}
\hline $\begin{array}{l}\text { Oswego } \\
\text { County } \\
\text { well } \\
\text { number }\end{array}$ & $\begin{array}{c}\text { USGS } \\
\text { well } \\
\text { number }\end{array}$ & Owner & $\begin{array}{l}\text { Year } \\
\text { com- } \\
\text { plet- } \\
\text { ed }\end{array}$ & $\begin{array}{c}\text { Type } \\
\text { of } \\
\text { we11 }\end{array}$ & $\begin{array}{l}\text { Depth } \\
\text { of } \\
\text { we11 } \\
(\mathrm{ft})^{1}\end{array}$ & $\begin{array}{l}\text { Depth } \\
\text { of } \\
\text { casing } \\
\text { (ft) }\end{array}$ & $\begin{array}{l}\text { Diam- } \\
\text { eter } \\
\text { (in) }\end{array}$ & $\begin{array}{l}\text { Depth } \\
\text { to bed- } \\
\text { rock } \\
\text { (ft) }\end{array}$ & $\begin{array}{c}\text { Aquifer } \\
\text { type } 2\end{array}$ & $\begin{array}{l}\text { Alti- } \\
\text { tude } \\
(\mathrm{ft})^{3}\end{array}$ & $\begin{array}{l}\text { Water } \\
\text { Depth } \\
\text { below } \\
\text { land } \\
\text { surface } \\
\text { (ft) }\end{array}$ & $\begin{array}{l}\text { Date of } \\
\text { measure- } \\
\text { ment }\end{array}$ & $\begin{array}{l}\text { Geol. } \\
\text { log }\end{array}$ & $\begin{array}{l}\text { Water } \\
\text { use } 4\end{array}$ & Remarks $^{5}$ \\
\hline \multicolumn{16}{|c|}{ OSWEGO WEST QUADRANGLE (continued) } \\
\hline OW -7 & $325-630-2$ & M. Moshier & 1956 & Dug & 15 & -- & 48 & -- & $\mathrm{Ti} 11$ & 380 & -- & - & No & $\mathrm{D}$ & Inadequate in sumer \\
\hline ow-8 & $325-630-1$ & E. Spaar & 1957 & Dr1 & 170 & 40 & 6 & 40 & Ss & 380 & 54.6 & $8-02-60$ & No & D & $\begin{array}{l}\text { Iron; yield (e) } \\
2 \mathrm{gal} / \mathrm{min}\end{array}$ \\
\hline ow-9 & $323-631-2$ & R. Schneider & 1968 & Dr1 & 67 & 44 & 6 & 44 & $S s-S \& G$ & 360 & -- & -- & No & $\mathrm{D}$ & Yield (r) $5 \mathrm{gal} /$ min \\
\hline \multicolumn{16}{|c|}{ PANTHER LAKE QUADRANGLE } \\
\hline $\mathrm{PL}^{-1}$ & $322-558-1$ & M. Rozoick & 1959 & Dug & 27 & -- & 36 & -- & Ti 11 & 640 & 14.1 & $9-07-60$ & No & $\mathrm{D}$ & \\
\hline $\mathrm{PL}-2$ & $322-556-1$ & E. Brude & 1951 & Dr1 & 130 & - & 6 & -- & Ss & 640 & 50.7 & $9-07-60$ & No & $\mathrm{D}$ & Yield (r) $2 \mathrm{gal} / \mathrm{min}$ \\
\hline $\mathrm{PL}-3$ & $322-553-1$ & American Te1 & 1956 & Dr1 & 189 & -- & 6 & - & Ss & 760 & 28.8 & $7-19-60$ & No & $\mathrm{c}$ & Yield (r) $8 \mathrm{gal} / \mathrm{min}$ \\
\hline $\mathrm{PL}-4$ & $316-555-1$ & L. Dodge & 1959 & Dr1 & 102 & -- & 6 & -- & $\mathrm{Ss}-\mathrm{Sh}$ & 580 & 28 & $7-20-60$ & No & $\mathrm{D}$ & $\mathrm{C} 1=1.0 \mathrm{mg} / \mathrm{L}, \quad 7-20-60$ \\
\hline $\mathrm{PL}-5$ & $320-553-1$ & Amboy School & 1935 & Drl & 55 & -- & 6 & -- & Ss & 580 & 11.7 & $7-20-60$ & No & In & $\mathrm{Cl}=.5 \mathrm{mg} / \mathrm{L}, \quad 7-20-60$ \\
\hline PL-6 & $319-554-1$ & Spoon & & & & & & & & & & & & & $\mathrm{C} 1=7.5 \mathrm{mg} / \mathrm{L}, \quad 7-20-60$ \\
\hline $\mathrm{PL}-7$ & $319-554-2$ & $\begin{array}{l}\text { Restaurant } \\
\text { V. Sellinger }\end{array}$ & $\begin{array}{l}1946 \\
1930\end{array}$ & $\begin{array}{l}\text { Dr1 } \\
\text { Dr1 }\end{array}$ & $\begin{array}{l}90 \\
27\end{array}$ & $\overline{27}$ & $\begin{array}{l}6 \\
1.25\end{array}$ & $\overline{-}$ & $\begin{array}{l}\text { Ss } \\
S \& G\end{array}$ & $\begin{array}{l}600 \\
600\end{array}$ & - & $\overline{-}$ & $\begin{array}{l}\text { No } \\
\text { No }\end{array}$ & $\begin{array}{l}\mathrm{C} \\
\mathrm{D}\end{array}$ & $\begin{array}{l}\mathrm{C} 1=7.5 \mathrm{mg} / \mathrm{L}, \quad 7-20-60 \\
\mathrm{C} 1=7.5 \mathrm{mg} / \mathrm{L}, 7-20-60\end{array}$ \\
\hline $\mathrm{PL}-8$ & $317-554-1$ & J. Darling & - & Dug & 19 & - & 24 & -- & $S \& G$ & 600 & 14.4 & $7-20-60$ & No & $\mathrm{D}$ & $\mathrm{Cl}=38 \mathrm{mg} / \mathrm{L}, \quad 7-20-60$ \\
\hline \multicolumn{16}{|c|}{ PENNELLVILLE QUADRANGLE } \\
\hline $\mathrm{Pe}-1$ & $318-615-1$ & F. Craner & 1947 & Dr1 & 91 & -- & 6 & -- & Ss & 440 & - & - & No & D & $\mathrm{H}_{2} \mathrm{~S} ; \mathrm{Fe}$ \\
\hline $\mathrm{Pe}-2$ & $319-618-2$ & M. DuBois & 1957 & Dr1 & 120 & 80 & 6 & 80 & Ss & 460 & 30 & 1957 & No & $\mathrm{D}$ & \\
\hline $\mathrm{Pe}^{-3}$ & $318-617-1$ & M. Rauhala & 1941 & Dr1 & 86 & 62 & 6 & 60 & Ss & 450 & 27.3 & $7-28-60$ & No & D & \\
\hline $\mathrm{Pe}^{-4}$ & $318-617-2$ & R. Kastler & 1957 & Dr1 & 64 & 60 & 6 & 60 & Ss & 450 & 13.2 & $7-28-60$ & No & D & \\
\hline$P E-5$ & $317-617-1$ & K. Reynolds & 1952 & Dr1 & 90 & 90 & 6 & 90 & $S \& G$ & 400 & 22.2 & $7-28-60$ & No & $\mathrm{D}$ & Yield (r) $20 \mathrm{gal} / \mathrm{min}$ \\
\hline $\mathrm{Pe}-6$ & $316-617-1$ & W. Phinney & 1950 & Dr1 & 116 & 54 & 6 & 54 & $\mathrm{Ss}-\mathrm{Sh}$ & 400 & 19 & $7-28-60$ & No & $\mathrm{D}$ & Hard; temp $48.5^{\circ} \mathrm{F}, 1960$ \\
\hline $\mathrm{Pe}-7$ & $316-622-1$ & R. Howard & 1957 & Dr1 & 45 & 45 & 6 & - & $S \& G$ & 430 & 17.3 & $3-27-61$ & No & $\mathrm{D}$ & $\begin{array}{l}\text { Hard; yield }(r) \\
5 \mathrm{gal} / \mathrm{min}\end{array}$ \\
\hline $\mathrm{Pe}-8$ & $315-621-1$ & $\begin{array}{l}\text { Great Bear } \\
\text { Spring Co. }\end{array}$ & 1959 & Dug & 10 & -- & 240 & - & $S \& G$ & 390 & -- & -- & No & $\mathrm{D}$ & Yield (m) $50 \mathrm{ga} 1 / \mathrm{min}$ \\
\hline $\mathrm{Pe}-9$ & $315-618-1$ & R. Haner & 1959 & Dri & 172 & -- & 6 & - & $\mathrm{Ss}-\mathrm{Sh}$ & 400 & - & -- & No & -- & Salty \\
\hline \multirow[t]{2}{*}{$\mathrm{Pe}-10$} & $321-616-1$ & Mexico Center & & & & & & & & & & & & & \\
\hline & & Sch.District & 1955 & Dug & 29 & -- & 18 & -- & Sand & 450 & 6.3 & $7-27-60$ & No. & Ps & Yield (r) $10 \mathrm{ga} 1 / \mathrm{min}$ \\
\hline $\mathrm{Pe}-11$ & $321-616-2$ & J. Sanders & 1941 & Dug & 140 & -- & 6 & -- & Ss & 470 & -- & -- & No & $\mathrm{U}$ & Salty \\
\hline $\mathrm{Pe}-12$ & $321-616-3$ & T. E1hage & 1958 & Dr 1 & 124 & 109 & 6 & 109 & Ss & 480 & 35 & 1958 & No & $\mathrm{D}$ & $\begin{array}{l}\mathrm{H}_{2} \mathrm{~S} ; \text { yield }(\mathrm{r}) \\
5 \mathrm{gal} / \mathrm{min}\end{array}$ \\
\hline $\mathrm{Pe}-13$ & $320-617-3$ & W. Whipple & 1957 & Dr1 & 68 & 68 & 6 & -- & $S \& G$ & 460 & -- & -- & No & $\mathrm{D}$ & Yield (r) $15 \mathrm{gal} / \mathrm{min}$ \\
\hline $\mathrm{Pe}-14$ & $320-617-1$ & A. McGinley & 1920 & DrI & 75 & 30 & 6 & 30 & Ss & 470 & 31.5 & $7-27-60$ & No & D & Hard \\
\hline $\mathrm{Pe}-15$ & $320-617-2$ & R. McGinley & 1959 & Dr1 & 43 & -- & 6 & -- & Ss & 470 & 29.6 & $7-28-60$ & No & $\mathrm{D}$ & \\
\hline $\mathrm{Pe}-16$ & $320-619-1$ & W.W. Hough & 1953 & Dr1 & 123 & 27 & 6 & 27 & Ss & 440 & -- & -- & No & $\mathrm{D}$ & Hard \\
\hline $\mathrm{Pe}-17$ & $320-619-2$ & T. Heaphy & 1962 & Dr1 & 2592 & -- & -- & -- & $-\infty$ & 462 & 75 & -- & Yes & $\mathrm{U}$ & Wildcat well \\
\hline $\mathrm{Pe}^{-18}$ & $319-617-1$ & J. Doss & 1956 & Drl & 41 & 41 & 6 & - & $S \& G$ & 460 & 5 & 1956 & No & D & Yield (r) $15 \mathrm{ga} 1 / \mathrm{min}$ \\
\hline PULASK I & QUADRANGLE & & & & & & & & & & & & & & \\
\hline $\mathrm{Pu}-1$ & $335-612-1$ & $\overrightarrow{\mathrm{k}}$. Brennan & -- & Drv & 13 & 11 & 1.25 & -- & Sand & 254 & 8 & $8-05-68$ & No & $\mathrm{D}$ & \\
\hline $\mathrm{Pu}-2$ & $333-611-1$ & C. Peters & -- & Dr1 & 126 & -- & 6 & - & Sh & 298 & 50 & $8-12-68$ & No & $\mathrm{D}$ & Poor well recovery: \\
\hline $\mathrm{Pu}-3$ & $336-607-1$ & M. Hurd & 1921 & Dr1 & 220 & 50 & 6 & 50 & $\mathrm{Sh}$ & 385 & 1 & $9-03-68$ & No & $\mathrm{U}$ & 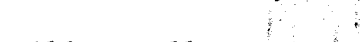 \\
\hline $\mathrm{Pu}-4$ & $331-610-1$ & Nicholson & 1964 & Dr1 & 1531 & - & -- & 40 & -- & 306 & 78 & - & Yes & $\mathrm{U}$ & Wildcat well \\
\hline
\end{tabular}


Table 1.--Data on Selected Wells in Oswego County (Continued)

[Locations are given in fig. 10; depths are in feet below National Geodetic Vertical Datum of 1929]

\begin{tabular}{|c|c|c|c|c|c|c|c|c|c|c|c|c|c|c|c|}
\hline $\begin{array}{l}\text { Oswego } \\
\text { County } \\
\text { we11 } \\
\text { number }\end{array}$ & $\begin{array}{c}\text { USGS } \\
\text { we11 } \\
\text { number }\end{array}$ & Owner & $\begin{array}{l}\text { Year } \\
\text { com- } \\
\text { plet- } \\
\text { ed }\end{array}$ & $\begin{array}{l}\text { Type } \\
\text { of } \\
\text { well } 1\end{array}$ & $\begin{array}{l}\text { Depth } \\
\text { of } \\
\text { well } \\
\text { (ft) }\end{array}$ & $\begin{array}{l}\text { Depth } \\
\text { of } \\
\text { casing } \\
\text { (ft) }\end{array}$ & $\begin{array}{l}\text { Dian- } \\
\text { eter } \\
\text { (in) }\end{array}$ & $\begin{array}{l}\text { Depth } \\
\text { to bed- } \\
\text { rock } \\
\text { (ft) }\end{array}$ & $\begin{array}{l}\text { Aquifer } \\
\text { type } 2\end{array}$ & $\begin{array}{l}\text { Alti- } \\
\text { tude } \\
(\mathrm{ft})^{3}\end{array}$ & $\begin{array}{l}\text { Depth } \\
\text { below } \\
\text { land } \\
\text { surf ace } \\
\text { (ft) }\end{array}$ & $\begin{array}{l}\text { Date of } \\
\text { measure- } \\
\text { ment }\end{array}$ & $\begin{array}{l}\text { Geol. } \\
\log \end{array}$ & $\begin{array}{l}\text { Water } \\
\text { use } 4\end{array}$ & Remarks 5 \\
\hline \multicolumn{16}{|c|}{ RICHLAND QUADRANGLE } \\
\hline $\mathrm{Ri}-\mathrm{l}$ & $336-602-1$ & D. Ridgeway & 1925 & Dr1 & 40 & 40 & 6 & $\ldots$ & Ss & 692 & 32 & $8-27-68$ & No & D & 8 \\
\hline $\mathrm{R} i-2$ & $335-606-1$ & H. Grinne1 & 1961 & Dug & 8 & -- & 42 & -- & Silt & 400 & 7 & $8-27-68$ & No & D & 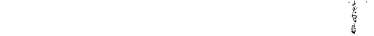 \\
\hline $\mathrm{Ri}-3$ & $335-600-1$ & J. Schroeder & -- & Dug & 12 & -- & 24 & -- & Till & 792 & 11 & $8-27-68$ & No & u & \\
\hline $\mathrm{Ri}-4$ & $334-603-1$ & R. Cornwel1 & 1961 & Dr1 & 50 & 50 & 6 & $-\rightarrow$ & $S \& G$ & 495 & 13 & $8-26-68$ & No & D & Good well recovery \\
\hline$R i-5$ & $332-601-1$ & R. Ackley & 1860 & Dug & 17 & -- & 60 & -- & $S \& G$ & 565 & 14 & $8-27-68$ & No & u & Good well recovery \\
\hline Ri-6 & $330-605-1$ & T. Orychkewyc & $\mathrm{ch}-$ & Dug & 19 & -- & 50 & -- & Sand & 450 & 8 & $8-14-68$ & No & D & \\
\hline$R i-7$ & $330-600-1$ & C. Durst & 1951 & Drl & 76 & 75 & 6 & -- & Ss & 580 & 22 & $8-14-68$ & No & D & \\
\hline \multirow[t]{2}{*}{$\mathrm{Ri}-8$} & $334-602-1$ & Schoeller & & & & & & & & & & & & & \\
\hline & & Paper Co. & 1968 & Dr1 & 43 & 43 & 6 & -- & $S \& G$ & 573 & 21.5 & $7-01-71$ & No & 0 & \\
\hline $\mathrm{Ri}-9$ & $334-602-2$ & Do & -- & DrI & 36 & 36 & 6 & -. & $S \& G$ & 551 & -.. & $-\ldots$ & No & 0 & \\
\hline$R i-10$ & $333-602-2$ & Do & 1968 & Drl & 51 & 51 & 6 & -- & $S \& G$ & 558 & 21 & $9-01-72$ & No & 0 & \\
\hline$R i-11$ & $333-602-3$ & Do & - & Dr1 & 58 & 58 & 12 & -- & $S \& G$ & 555 & -- & - & No & I & $\begin{array}{l}\text { Hardness } \\
\left(\text { as } \mathrm{CaCO}_{3}\right)=108,3-10-77\end{array}$ \\
\hline$R i-12$ & $334-601-1$ & Do & -.- & Dr 1 & 38 & 38 & 6 & -- & $S \& G$ & 580 & $\ldots$ & -- & No & 0 & \\
\hline $\mathrm{Ri}-13$ & $334-601-2$ & Do & -- & Drl & 49 & 49 & 12 & - & $S \& G$ & 559 & -- & -- & No & I & $\begin{array}{l}\text { Hardness } \\
\left(\text { as } \mathrm{CaCO}_{3}\right)=196,3-10-77\end{array}$ \\
\hline $\mathrm{Ri}-14$ & $334-602-3$ & Do & 1968 & Drl & 47 & 47 & 6 & -- & $S \& G$ & 569 & -- & - & No & 0 & \\
\hline SANDY C & CREEK QUADRAI & NGLE & & & & & & & & & & & & & \\
\hline \multirow[t]{2}{*}{$s c-1$} & $338-606-1$ & Reserve & & & & & & & & & & & & & \\
\hline & & Gas Co. & 1962 & Drl & 1393 & $\ldots$ & $\ldots$ & 9 & $\ldots$ & 416 & 90 & -- & Yes & $\mathrm{u}$ & Wildcat well \\
\hline $5 \mathrm{C}-2$ & $337-605-1$ & D. Payne & $\ldots$ & Dr1 & 65 & -- & 6 & - & Sh & 501 & 19 & $8-27-68$ & No & D & \\
\hline $\mathrm{sc}-3$ & $340-604-1$ & J. Ye11 & 1967 & Drl & 37 & 30 & $b$ & $\cdots$ & $\mathrm{Sh}$ & 513 & 1 & $8-27-68$ & No & D & \\
\hline \multirow[t]{2}{*}{$S C-4$} & $339-604-4$ & Town of & & & & & & & & & & & & & \\
\hline & & Sandy Creek & 1965 & DrI & 42 & $\ldots$ & $\ldots$. & 38 & $S \& G$ & 554 & -- & -. & Yes & $\mathrm{u}$ & Test ve11 \\
\hline$s c-5$ & $340-604-3$ & Do & 1965 & Dr1 & 25 & -- & 24 & 26 & $S \& G$ & 539 & $-\cdots$ & - & Yes & PS & $\begin{array}{l}\text { Production well; } \\
\text { yield }(x) 400 \text { gal } / \mathrm{min}\end{array}$ \\
\hline $\mathrm{sc}-6$ & $340-604-4$ & Do & 1.965 & Dr1 & 30 & -. & $\ldots$ & 28 & $S \& G$ & 542 & -- & $\ldots$ & Yes & U & Test we11 \\
\hline $\mathrm{sc}-7$ & $340-604-2$ & Do & 1965 & Dr1 & 32 & $-\cdots$ & 24 & 32 & $S \& G$ & 546 & -- & -- & Yes & PS & $\begin{array}{l}\text { Production well; } \\
\text { yield (r) } 200 \mathrm{gal} / \mathrm{min}\end{array}$ \\
\hline $\mathrm{sc}-8$ & $339-601-1$ & C. Caufield & $\ldots$ & Dug & 11 & -- & 36 & -- & $S \& G$ & 781 & 9 & $8-27-68$ & No & D & \\
\hline $\mathrm{SC}-9$ & $340-601-1$ & F. Stone & -- & Dug & 17 & -- & 48 & - & Till & 872 & 11 & $8-27-68$ & No & D & \\
\hline TEXAS Q & QUADRANGLE & & & & & & & & & & & & & & \\
\hline $\mathrm{Te}-1$ & $330-620-1$ & A. Cota & 1967 & Drl & 32 & - & 6 & -- & Ss & 310 & 18 & $8-07-68$ & No & D & Yield (r) $8 \mathrm{gal} / \mathrm{min}$ \\
\hline $\mathrm{Te}-2$ & $330-617-1$ & R. Rebbeor & -. & Dr1 & 43 & 43 & 6 & -- & Ss & 265 & 12 & $8-07-68$ & No & D & Yield (e) $12 \mathrm{gal} / \mathrm{min}$ \\
\hline $\mathrm{Te}-3$ & $330-618-1$ & M. Leichman & 1975 & Dr1 & 16 & -- & 6 & 12 & Ss & 293 & 15 & - & Yes & $\mathrm{D}$ & \\
\hline \multicolumn{16}{|c|}{ WESTDALE QUADRANGLE } \\
\hline We-1 & $329-548-1$ & x. Poole & 1963 & $\operatorname{Dr} 1$ & 76 & 54 & 6 & 54 & Ss & 925 & 40 & 1963 & No & $\mathrm{D}$ & $\begin{array}{l}\text { Yield (m) } 18 \mathrm{gal} / \mathrm{min} ; \\
\mathrm{Cl}=13 \mathrm{mg} / \mathrm{L}, 7-21-64\end{array}$ \\
\hline
\end{tabular}




\begin{tabular}{|c|c|c|c|c|c|c|c|c|c|c|c|c|c|c|c|}
\hline $\begin{array}{l}\text { Oswego } \\
\text { County } \\
\text { wel1 } \\
\text { number } \\
\end{array}$ & $\begin{array}{c}\text { USGS } \\
\text { well } \\
\text { number }\end{array}$ & Owner & $\begin{array}{l}\text { Year } \\
\text { com- } \\
\text { plet- } \\
\text { ed }\end{array}$ & $\begin{array}{l}\text { Type } \\
\text { of } \\
\text { we11 } 1\end{array}$ & $\begin{array}{l}\text { Depth } \\
\text { of } \\
\text { well } \\
(\mathrm{ft}) \\
\end{array}$ & $\begin{array}{l}\text { Depth } \\
\text { of } \\
\text { casing } \\
\text { (ft) }\end{array}$ & $\begin{array}{l}\text { Diam- } \\
\text { eter } \\
\text { (in) }\end{array}$ & $\begin{array}{l}\text { Depth } \\
\text { to bed- } \\
\text { rock } \\
\text { (ft) }\end{array}$ & $\begin{array}{l}\text { Aquifer } \\
\text { type } 2\end{array}$ & $\begin{array}{l}\text { Alti- } \\
\text { tude } \\
(\mathrm{ft})^{3}\end{array}$ & $\begin{array}{l}\text { Water } \\
\text { Depth } \\
\text { below } \\
\text { land } \\
\text { surface } \\
\text { (ft) }\end{array}$ & $\begin{array}{l}\text { Date of } \\
\text { measure- } \\
\text { ment }\end{array}$ & $\begin{array}{l}\text { Geol. } \\
\text { log }\end{array}$ & $\begin{array}{l}\text { Water } \\
\text { use } 4\end{array}$ & Remarks $^{5}$ \\
\hline \multicolumn{16}{|c|}{ WESTDALE QUADRANGLE (continued) } \\
\hline We -2 & $327-552-1$ & H. Wiggins & 1958 & Dr1 & 19 & 19 & 6 & 19 & Ss & 780 & 9.2 & $9-19-60$ & No & $\mathrm{D}$ & Yield (e) $10 \mathrm{gal} / \mathrm{min}$ \\
\hline We -3 & $325-5.51-1$ & J. Britton & 1930 & Dug & 20 & - & -- & -- & $\mathrm{Ti} 11$ & 760 & 17 & $7-10-80$ & No & $\mathrm{D}$ & \\
\hline We-4 & $324-551-1$ & L. Burminghan & $\operatorname{m1977}$ & Dr1 & 62 & 12 & 6 & 12 & $\mathrm{Sh}$ & 630 & 55 & 1979 & Yes & $\mathrm{D}$ & Yield (r) $4 \mathrm{gal} / \mathrm{min}$ \\
\hline \multicolumn{16}{|c|}{ WILLIAMSTOWN QUADRANGLE } \\
\hline Wi-1 & $328-555-1$ & C. Cox & 1963 & Drl & 53 & 53 & 6 & -- & $S \& G$ & 640 & 18.9 & $7-28-64$ & No & D & \\
\hline Wi-2 & $328-555-2$ & C. Roser & 1953 & Dr1 & 80 & 80 & 6 & -- & Ss & 684 & 37 & $8-14-68$ & No & D & \\
\hline Wi-3 & $327-556-1$ & J. McCullagh & 1967 & Dr1 & 40 & 10 & 6 & 10 & Ss & 655 & 17 & $8-14-68$ & No & D & \\
\hline$W i-4$ & $326-553-1$ & Kellogg & 1962 & Dr 1 & 1697 & 292 & 10 & - & -- & 730 & 68 & 1967 & Yes & $\mathrm{U}$ & Wildcat we11 \\
\hline$W i-5$ & $325-553-1$ & Sage & 1959 & Dug & 9 & 9 & 76 & -- & $S \& G$ & 603 & 26 & $7-19-60$ & No & In & $\mathrm{C} 1=.5 \mathrm{mg} / \mathrm{L}, 7-19-60$ \\
\hline \multirow[t]{2}{*}{ Wi-6 } & $325-553-2$ & Dairyman's & & & & & & & & & & & & & \\
\hline & & League & 1916 & Dr1 & 80 & 75 & 6 & 75 & Ss & 600 & 50 & $10-14-59$ & No & $\mathrm{C}$ & $\mathrm{Cl}=21 \mathrm{mg} / \mathrm{L}, \quad 7-20-60$ \\
\hline Wi-7 & $323-559-1$ & M. Roziock & -- & Dug & 27 & -- & 36 & -- & Till & 640 & 14.1 & $9-07-60$ & No & $\mathrm{D}$ & $\mathrm{C} 1=13 \mathrm{mg} / \mathrm{L}, 9-07-60$ \\
\hline $\mathrm{Wi}-8$ & $325-553-3$ & M. Castle & 1979 & Drl & 126 & 126 & 8 & - & Grvl & 600 & 22 & 1979 & Yes & $\mathrm{D}$ & Yield (r) $7 \mathrm{gal} / \mathrm{min}$ \\
\hline Wi-9 & $329-555-1$ & G. Trumble & 1978 & Dr1 & 38 & 35 & 6 & 35 & Ss & 695 & 20.8 & $8-10-80$ & No & $\mathrm{D}$ & Yield (r) $9 \mathrm{gal} / \mathrm{min}$ \\
\hline Wi-10 & $328-557-1$ & A. Trumble & 1962 & Dr1 & 96 & 90 & 6 & 88 & Ss & 685 & -- & -- & No & $\mathrm{D}$ & \\
\hline
\end{tabular}

